University of Nebraska - Lincoln

DigitalCommons@University of Nebraska - Lincoln

1985

\title{
Effect of Dietary Fat on Pig Performance and Dust Levels in Modified-Open-Front and Environmentally Regulated Confinement Buildings
}

\author{
L. I. Chiba \\ University of Nebraska-Lincoln \\ E. R. Peo, Jr. \\ University of Nebraska-Lincoln
}

\author{
A. J. Lewis \\ University of Nebraska-Lincoln, alewis2@unl.edu \\ M. C. Brumm \\ University of Nebraska-Lincoln, mbrumm@hickorytech.net \\ R. D. Fritschen \\ University of Nebraska-Lincoln, bobnhaz@hotmail.com \\ See next page for additional authors
}

Follow this and additional works at: https://digitalcommons.unl.edu/animalscifacpub

Part of the Animal Sciences Commons

Chiba, L. I.; Peo, Jr., E. R.; Lewis, A. J.; Brumm, M. C.; Fritschen, R. D.; and Crenshaw, J. D., "Effect of Dietary Fat on Pig Performance and Dust Levels in Modified-Open-Front and Environmentally Regulated Confinement Buildings" (1985). Faculty Papers and Publications in Animal Science. 671.

https://digitalcommons.unl.edu/animalscifacpub/671

This Article is brought to you for free and open access by the Animal Science Department at DigitalCommons@University of Nebraska - Lincoln. It has been accepted for inclusion in Faculty Papers and Publications in Animal Science by an authorized administrator of DigitalCommons@University of Nebraska - Lincoln. 


\section{Authors}

L. I. Chiba; E. R. Peo, Jr.; A. J. Lewis; M. C. Brumm; R. D. Fritschen; and J. D. Crenshaw 


\title{
EFFECT OF DIETARY FAT ON PIG PERFORMANCE AND DUST LEVELS IN MODIFIED-OPEN-FRONT AND ENVIRONMENTALLY REGULATED CONFINEMENT BUILDINGS ${ }^{1,2,3}$
}

\author{
L. I. Chiba, E. R. Peo, Jr., A. J. Lewis, M. C. Brumm, \\ R. D. Fritschen and J. D. Crenshaw \\ University of Nebraska ${ }^{4}$, \\ Lincoln 68583-0908
}

\begin{abstract}
Four trials were conducted with 1,480 pigs (initial wt: $23 \mathrm{~kg}$ in trial $1,29 \mathrm{~kg}$ in trial 2 and 49 $\mathrm{kg}$ in trial 3 and 4 ) to determine the effect of dietary fat on pig performance, nutrient separation in an automated feed distribution system, dust levels in swine buildings and integrity of the respiratory system of swine. Two modified-open-front (B-1 and B-2) and two environmentally regulated (E-1 and $\mathrm{E}-2$ ) growing-finishing buildings, of identical design, were used in each trial. In trial 1, 250 pigs (25 pens of 10 pigs/pen) in B-1 were fed a ground, mixed, corn-soybean meal diet (15\% crude protein) with added tallow (5\%), and 250 pigs in B-2 were fed the same diet but without added tallow. The assignment of diets to buildings were reversed in trial 2 in which $2.5 \%$ tallow was used instead of $5 \%$. Each diet was fed ad libitum to pigs, and was distributed by an automated "Flexauger" system in trials 1 and 2 . In each of trials 3 and 4, 120 pigs (12 pens of 10 pigs/pen) in E-1 were fed a corn-soybean meal diet ( $14 \%$ crude protein) with added tallow (5\%) and 120 pigs in E-2 were fed the same diet but without added tallow. Overall, pigs fed the diet with tallow gained faster $(P<.002)$, consumed less feed $(P<.02)$ and converted feed more efficiently $(P<.002)$ than those fed the diet without tallow in trials 1 and 2 . Pig performance was also improved by the addition of tallow to the diet in trials 3 and $4(\mathrm{P}<.002)$. Crude protein, $\mathrm{Ca}, \mathrm{P}$ and $\mathrm{Cu}$ contents of both diets were similar at each location sampled throughout the automated distribution system in trials 1 and 2. Addition of tallow to the diets reduced aerial dust levels, both with the feed distribution auger running $(P<.002)$ and without the auger running $(P=.06)$ in trials 1 and 2 . In trials 3 and 4 , adding $5 \%$ tallow to the diet reduced aerial dust concentrations of particle sizes of 14,4 , and $1.5 \mu \mathrm{m}(P<.002)$ and $.4 \mu \mathrm{m}(P=.07)$. The amount of settled dust was lower $(P<.001$, trials 1,3 and 4) when tallow was included in the diet. There was no difference between the two dietary treatments in the incidence of abnormal turbinates in all four trials. There was a trend for pigs fed the diet without tallow to have more severe forms of lung lesions than those fed the diet with tallow in trials 1 and 3 . The results of microscopic examination and crude protein analysis of settled dust indicated that the swine-house dust was mainly feed dust.
\end{abstract}

(Key Words: Animal Housing, Tallow, Dust, Pigs.)

\section{Introduction}

Swine-house dust is potentially dangerous not only as a carrier of pathogenic microorganisms and harmful gases, but also because

\footnotetext{
${ }^{1}$ Published as Paper No. 7662, Journal Series, Nebraska Agr. Exp. Sta.

${ }^{2}$ Acknowledgement is made to Dr. J. A. DeShazer for the use of instruments, and to M. B. Barnes, J. L. Kovar, D. J. Smith, D. A. Burosh and members of the Field Laboratory Staff, the Northeast Research and Extension Center staff, the Dept. of Vet. Sci. and the Nebraska SPF staff for technical assistance.

${ }^{3}$ Supported in part by a grant from the Fats and Protein Research Foundation, Des Plaines, IL.

${ }^{4}$ Dept. of Anim. Sci.

Received December 26, 1984.

Accepted June 11, 1985.
}

of its direct adverse effect on both humans and animals (Honey and McQuitty, 1976; Cermak and Ross, 1978). In humans, dust can induce acute or chronic malfunction of the respiratory tract producing symptoms such as coughing, chest tightness, wheezing, stuffy nose, shortness of breath, eye irritation or lacrimation, headache and dizziness (Cermak and Ross 1978; Donham and Gustafson, 1982). Jericho (1968) and Martin and Willoghby (1972) have suggested that raising swine in a dusty condition may predispose animals to respiratory diseases. Adverse effects of dust on buildings and equipment (Notestine and Pfost, 1965; Bundy et al., 1974; Bundy and Hazen, 1975; Owen, 1982), and swine-house odor (Day et al., 1965; Burnett, 1969; Cermak and Ross, 1978; Hammond et al., 1979; Curtis, 1981) have been noted. 
Animal fat such as tallow or lard is an excellent source of energy for swine. The possible advantages of including fat in growingfinishing and sow diets have been reviewed by Moser (1977) and Moser and Lewis (1980; 1981). In commercial pork production, the use of animal fat in swine diets is largely dependent on the cost of energy from grain versus animal fat (Green, 1983; Peo and Chiba, 1984). However, Wilder (1960) and Green (1983) have pointed out that including fat in swine diets has many advantages in addition to providing a source of digestible energy. Most of the dust in swine buildings is derived from feed (Curtis et al., 1975b; Honey and McQuitty, 1979). Dietary fat tends to bond minute particles together, and therefore may play an important role in reducing swine-house dust, which might otherwise be a health hazard for both humans and swine. Also, fat may aid in preventing mechanical separation of feed ingredients when using automated feed distribution systems that extend $50 \mathrm{~m}$ or more.

Four trials were conducted to determine the effect of adding animal fat to the diet of growing-finishing swine on: (1) weight gains and feed conversion, (2) aerial dust concentration and dust accumulation in modifiedopen-front (MOF) and environmentally regulated (ER) buildings, (3) the integrity of the respiratory system of swine and (4) nutrient separation in an automated feed distribution system.

\section{Experimental Procedures}

\section{Trials 1 and 2}

Two trials (trial 1, November, 1982 to February, 1983 and trial 2, March to May, 1984) were conducted utilizing two MOF buildings and a total of 1,000 growing-finishing pigs. The experimental procedures were similar for both trials.

Buildings and Animals. Two naturally ventilated MOF growing-finishing buildings of

\footnotetext{
${ }^{5}$ Bristol's Thermo-Humidigraph (Model 569 1265A), Bristol Bobcock Inc., Waterbury, CT 06708.

${ }^{6}$ Brock Manufacturing, Inc., Milford, IN $\mathbf{4 6 5 4 2}$

${ }^{7}$ Lundgren Impactor (Model 4220), Environmental Research Corp., St. Paul, MN 55112.

${ }^{8}$ Mylar film, Transilwrap Co., Kansas City, MO 64132 .

${ }^{9}$ Dow Corning high vacuum grease, Dow Corning Corp., Midland, MI 48640.
}

identical design and located $40 \mathrm{~m}$ apart were used in the study. Each building contained 25 pens $1.5 \mathrm{~m}$ wide by $4.8 \mathrm{~m}$ long. Temperature and relative humidity of the buildings were monitored continuously using thermohumidigraphs $^{5}$ (see figure 1 for results). Five hundred crossbred pigs, averaging $23 \mathrm{~kg}$ for trial 1 and $29 \mathrm{~kg}$ for trial 2, were sorted on the basis of sex and weight, and allotted to the treatments with $10 \mathrm{pigs} / \mathrm{pen}$ in each trial. Each treatment was assigned equal numbers of barrows and gilts. Pig weights and feed consumption data were collected biweekly for $8 \mathrm{wk}$. Criteria of performance response were: average daily gain (ADG), average daily feed intake (ADFI) and feed to gain ratio $(F: G)$.

Diets. The composition of the diets is presented in table 1 . The diets were formulated with corn and soybean meal to contain 15\% crude protein. For diet $1,5 \%$ tallow $(2.5 \%$ in trial 2) was added in the place of ground corn, and consequently contained $220 \mathrm{kcal}$ more energy per $\mathrm{kg}$ of feed $(113 \mathrm{kcal} / \mathrm{kg}$ more in trial 2) than diet 2. In trial 1, the 250 pigs in Building 1 were fed the diet with tallow (W/T) and those in Building 2 were fed the diet without tallow (WO/T). Assignment of diets to buildings was reversed (by random allotment) in trial 2. Each diet was distributed to a feeder in each pen by an automated "Flex-auger"- system ${ }^{6}$. Feed samples were taken directly from drops during each trial at 25 feeder locations along the length of the distribution system for analysis of crude protein, Ca, P and Cu (AOAC, 1980).

Aerial Dust Measurements. Aerial dust levels in the MOF buildings, with and without the feed distribution auger running, were measured using a four-stage, cascade-type impactor ${ }^{7}$ that separates particles into size classes. The air to be sampled was drawn into the impactor by a vacuum pump and the dust particles were collected on rotating drums. With a sampling rate of $.071 \mathrm{~m}^{3} / \mathrm{min}$, the $50 \%$ cutpoints were $14,4,1.5$ and $.4 \mu \mathrm{m}$ for stages $1,2,3$ and 4 , respectively. The $50 \%$ cutpoints are defined as the particle size for which the efficiency of the stage is $50 \%$. The collection drum surfaces were covered with substrate ${ }^{8}$. To prevent "bounce off" of the particles, a viscous material ${ }^{9}$ was applied on the surfaces. A silicon grease was spread onto the substrate and the surface was then wiped with a smooth, dry tissue to make the grease layer uniform and to remove any excess grease. The prepared drums were placed in a dessicator for $18 \mathrm{~h}$ before and after 
Triat 1

TRIAL 2

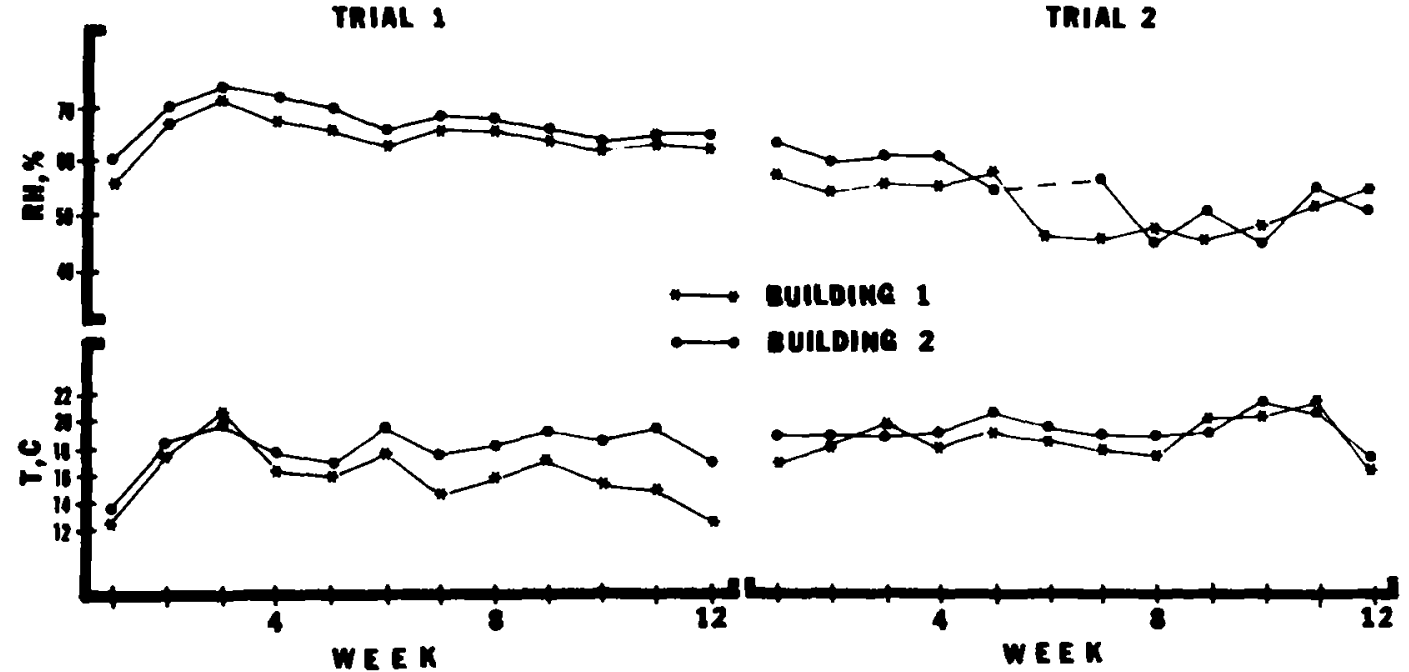

Figure 1. Temperature (T) and relative humidity (RH) in modified-open-front buildings (trials 1 and 2 ). A diet containing $5 \%$ tallow was used in Building 1, whereas diet containing $2.5 \%$ tallow was used in Building 2 for trials 1 ahd 2, respectively.

TABLE 1. COMPOSITION OF EXPERIMENTAL DIETS (TRIALS 1, 2, 3 AND 4)

\begin{tabular}{|c|c|c|c|c|c|c|}
\hline \multirow[b]{3}{*}{ Item } & \multicolumn{6}{|c|}{ Trial } \\
\hline & \multicolumn{2}{|c|}{1} & \multicolumn{2}{|c|}{2} & \multicolumn{2}{|c|}{3 and 4} \\
\hline & Dietª $^{2}(W / T)$ & $\begin{array}{l}2 \\
\text { (WO/T) }\end{array}$ & $\begin{array}{l}1 \\
(W / T)\end{array}$ & $\begin{array}{l}2 \\
\text { (WO/T) }\end{array}$ & $\begin{array}{l}1 \\
(W / T)\end{array}$ & $\begin{array}{l}2 \\
\text { (WO/T) }\end{array}$ \\
\hline \multicolumn{7}{|l|}{ Ingredients, $\%$} \\
\hline Corn (IFN 4-02-992) & 71.70 & 77.95 & 74.32 & 77.07 & 74.50 & 80.74 \\
\hline Soybean meal (IFN 5-04-604) & 20.05 & 18.85 & 19.71 & 19.48 & 17.25 & 16.04 \\
\hline Tallow (IFN 4-07-880) & 5.00 & & 2.50 & & 5.00 & \\
\hline Limestone (IFN 6-02-632) & .95 & .95 & .91 & .93 & .93 & .96 \\
\hline \multicolumn{7}{|l|}{ Dicalcium phosphate } \\
\hline (IFN 6-01-080) & .95 & .90 & 1.21 & 1.17 & 1.02 & .96 \\
\hline Salt (IFN 6-04-151) & .25 & .25 & .25 & .25 & .25 & .25 \\
\hline Trace mineral premix b & .05 & .05 & .05 & .05 & .05 & .05 \\
\hline Vitamin premix $c$ & 1.00 & 1.00 & 1.00 & 1.00 & 1.00 & 1.00 \\
\hline \multirow[t]{2}{*}{ Selenium premix ${ }^{d}$} & .05 & .05 & .05 & .05 & & \\
\hline & 100.00 & 100.00 & 100.00 & 100.00 & 100.00 & 100.00 \\
\hline \multicolumn{7}{|l|}{ Calculated analysis } \\
\hline Crude protein, $\%$ & 15.00 & 15.00 & 15.07 & 15.20 & 14.00 & 14.00 \\
\hline Calcium, \% & .65 & .65 & .70 & .70 & .66 & .65 \\
\hline Phosphorus, $\%$ & .50 & .50 & .55 & .55 & .50 & .50 \\
\hline Copper, ppm & 9.72 & 9.50 & 9.68 & 9.69 & 8.79 & 8.57 \\
\hline
\end{tabular}

${ }^{2} \mathbf{W} / \mathrm{T}=$ with tallow; wOrT $=$ without tallow.

${ }^{\mathrm{b}}$ Contributed in Ppm: $\mathrm{Zn}, 100 ; \mathrm{Fe}, 50 ; \mathrm{Mn}, 27.5 ; \mathrm{Cu}, 5 ; \mathrm{I}, .75$.

'Contributed per kg of diet: vitamin A, 3,307 IU; vitamin D, 551 IU; vitamin E, 11 IU; riboflavin, $2.2 \mathrm{mg}$; d-pantothenic acid, $9.9 \mathrm{mg}$; niacin $17.6 \mathrm{mg}$; choline chloride, $220 \mathrm{mg}$; vitamin $B_{12}, .022 \mathrm{mg}$; ethoxyquin, 4.4 mg. (Added chlortetracycline to the diets, $50 \mathrm{~g} / \mathrm{ton}$ ).

d Contributed .1 Ppm Se. 
the sampling (Jacobson, 1974), and weighed. Dust concentrations in both MOF buildings were measured on the same day.

Aerial Dust Concentrations Witbout Auger Running. Aerial dust concentrations without the feed distribution auger running were measured before moving pigs into the buildings, biweekly in trial 1 and weekly thereafter. The dust collection drums were set for one revolution $/ 2 \mathrm{~h}$ for the first four samplings in trial 1 and one revolution/1 $\mathrm{h}$ thereafter (actual sampling time was 104 and $52 \mathrm{~min}$ for 2 and 1 $h$, respectively). The order of sampling was alternated such that Building 1 was measured first, then Building 2 and vice versa in the next sampling period. In each instance, the impactor was placed approximately $.75 \mathrm{~m}$ above the floor in the alley near the feeders. Each measurement was taken from three locations, i.e., $17.3 \mathrm{~min}$ in the first third, $17.3 \mathrm{~min}$ in the middle and $17.3 \mathrm{~min}$ in the last third of the length of the buildings for a total sampling time of $52 \mathrm{~min}$. The buildings were closed completely during the samplings. Animal activities during the sampling were assessed using the following criteria (Honey and McQuitty, 1976):

Q: quiet (more than $80 \%$ of the animals lying down);

A: active (between 20 and $80 \%$ of the animals moving about);

VA: very active (more than $80 \%$ of the animals moving about).

Temperature and relative humidity were recorded during sampling.

Aerial Dust Concentrations With Auger Running. Aerial dust concentrations with the feed distribution auger running were measured during the filling of the feeders. Feeders at the regions to be sampled on a given day were nearly empty so that filling continued for the entire $10.5 \mathrm{~min}$ filling time $/ \mathrm{sampling}$ period. Filling of all other feeders was completed after sampling. The impactor was placed approximately $1.3 \mathrm{~m}$ above the floor in the alley near the randomly assigned feeder to be filled.

Settled Dust Measurements. Settled dust measurements were made by weighing the dust

\footnotetext{
${ }^{10}$ Sterile disposable petri dish, Lab-Tek Division, Miles Laboratories, Inc., Naperville, IL 60540.

11 Dr. A. R. Doster, Dept. of Vet. Sci., Univ. of Nebraska, Lincoln, NE 68583.
}

that settled on a 9 -cm diameter petri dish ${ }^{10}$. Twelve petri dishes were equally spaced throughout each building and were placed approximately $1.5 \mathrm{~m}$ above the floor. The petri dishes were placed in a dessicator for $20 \mathrm{~h}$ and then weighed after the collection of dust for $53 \mathrm{~d}$ (growing phase) and $30 \mathrm{~d}$ (finishing phase) in trial 1 , and $27 \mathrm{~d}$ in trial 2 (jars were used from $56 \mathrm{~d}$ to term). The settled dust was analyzed for crude protein by the Kjeldahl procedure (AOAC, 1980).

Gross Examination of Lungs and Snouts. The lungs and snouts of a representative sample of pigs from each building were examined for gross pathological lesions at the end of both trials. Thirty pigs from diet 1 and 26 pigs from diet 2 in trial 1 , and 33 and 30 pigs from the two respective diets in trial 2 were examined. The snouts were sawed in cross section at the first premolar tooth, and the largest opening between the turbinates and the wall of the nasal cavity on both sides was measured. If the opening was $\geqslant 6 \mathrm{~mm}$, the pig was recorded as being suspect for rhinitis. The lungs were evaluated for gross lesions by a pathologist ${ }^{11}$. Gross lesions of the lungs were subjectively categorized as follows (Huhn, 1970):

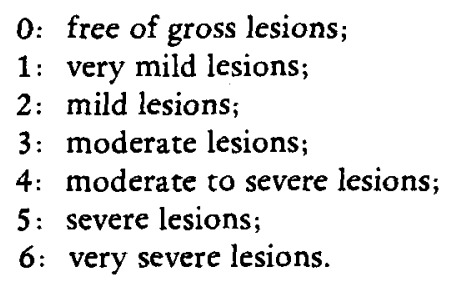

Statistical Analysis. Although the levels of dietary inclusion of tallow in the two trials were different, the two data sets were combined to incorporate building effect into the statistical model. The effect of adding tallow to the diet of growing-finishing swine diet on performance was analyzed as a generalized randomized block design (Addelman, 1969) with a split-plot arrangement (Steel and Torrie, 1980). Aerial dust levels were tested as a randomized compiete-block design with a split-plot arrangement. A general linear model procedure was used for computation (SAS, 1979). The lung and snout data were analyzed using the chi-square test on a row $X$ column contingency table (Steel and Torrie, 1980), and the funcat procedure (SAS, 1979). The funcat procedure models function of categorical response as a linear model. It uses generalized least-squares to produce minimum 
chi-square estimates. The results of nutrients analyses were tested using regression analysis for each diet, and the homogeniety of the two regression coefficients was tested by a t-test.

\section{Trials 3 and 4}

Two trials (trial 3: April to June, 1983 and trial 4: September to November, 1983) were conducted utilizing two growing-finishing swine buildings (E-1 and E-2) and a total of 480 finishing pigs. The experimental procedures were similar for each trial.

Two environmentally regulated growingfinishing buildings, whose design is similar, were used in the study (Shelton and Schulte, 1982). The buildings measured $11.6 \times 11.4 \mathrm{~m}$ and held 120 pigs. Each building contained 12 pens that were $1.8 \mathrm{~m}$ wide by $4.8 \mathrm{~m}$ long. The temperature and relative humidity were monitored continuously. Two hundred forty crossbred pigs, averaging $49 \mathrm{~kg}$, were sorted on the basis of sex and weight and assigned to the two dietary treatments with 10 pigs/pen.

The composition of the diets is presented in table 1. Two corn-soybean meal-based diets were formulated to contain $14 \%$ crude protein and were fed in meal-form. For dier 1, 5\% tallow was added in place of ground corn; it thus contained $222 \mathrm{kcal}$ more metabolizable energy $/ \mathrm{kg}$ of feed than diet 2 . The 120 pigs in E-1 were fed the diet with tallow (W/T), whereas those in E-2 were fed the diet without tallow $(W O / T)$. Feeders were filled by hand. Feed and water were offered ad libitum. Pig weights and feed consumption data were collected biweekly for 9 and 8 wk for trial 3 and 4 , respectively.

Aerial dust concentrations in the buildings were measured weekly using the procedures described previously. In each measurement, dust was collected 26 min facing north and then $26 \mathrm{~min}$ facing south (pens were on the north and south sides of the alley). All fans, except two tube-axial propeller fans located outside the building in manure pit annexes, were turned off during dust sampling. The procedures for the settled dust determination were the same as trials 1 and 2, except for the number of petri dishes (10/building) and the duration of collection ( $49 \mathrm{~d}$ in trial 3 and $53 \mathrm{~d}$ in trial 4).

The integrity of respiratory structures was assessed using procedures described previously for trials 1 and 2 .
The procedures for statistical analysis were also the same as used for trials 1 and 2, except performance, aerial dust concentration, and the amounts of settled dust were analyzed as a randomized complete-block design with a split-plot in time arrangement (Steel and Torrie, 1980).

\section{Results and Discussion}

\section{Trials 1 and 2}

No significant building effect was observed except in one instance (table 4). Temperature and relative humidity were similar for both buildings in each trial (figure 1). Pig performance was improved and the dust levels were reduced by the addition of tallow to the diets regardless of buildings and levels of fat used in the two trials. Also, similar results were obtained in trials 3 and 4 that utilized identically designed, environmentally regulated growing-finishing buildings. Therefore, it is unlikely that the assignment of one treatment to one particular swine building or the other had any significant impact upon the treatment differences observed.

Performance. The effects of dietary tallow on gain and feed conversion are summarized in table 2. Pigs fed a diet containing $5 \%$ tallow in trial 1 gained $8.3 \%$ faster, consumed $5.3 \%$ less feed and were $12.6 \%$ more efficient in converting feed to gain than pigs fed a diet containing no tallow. These findings were expected and agree with the reports of Barrick et al. (1953), Day et al. (1953), Heitman (1956), Sewell et al. (1958), Clawson et al. (1962), Moser et al. (1975), Moser (1977) and Keaschall et al. (1983). In trial 2, ADG and ADFI were similar for both treatments but F:G was improved by $2.8 \%$ when $2.5 \%$ tallow was included in the diet.

Although there were slight differences in temperature and relative humidity between the two buildings (figure 1), these were not considered large enough to have any appreciable impact on swine performance (Heitman et al., 1958; Morrison et al., 1966, 1969; Bond, 1974; Scott et al., 1982; Ames and Ray, 1983). Overall, the pigs fed the diets containing tallow consumed less feed $(1.81 \mathrm{vs} 1.87 \mathrm{~kg}, \mathrm{P}<.02)$, gained faster (.69 vs $.66 \mathrm{~kg}, \mathrm{P}<.002)$ and had an improved feed conversion (2.62 vs 2.83 , $\mathrm{P}<.002$ ) compared with the pigs fed diets containing no tallow. 
TABLE 2. EFFECT OF TALLOW ON PERFORMANCE OF PIGS REARED IN MOF BUILDINGS (TRIALS 1 AND 2)

\begin{tabular}{|c|c|c|c|}
\hline \multirow[b]{2}{*}{ Item } & \multicolumn{2}{|c|}{ Diet $^{\mathrm{a}}$} & \multirow[b]{2}{*}{$\mathrm{CV}^{\mathrm{b}}, \%$} \\
\hline & $1(\mathrm{~W} / \mathrm{T})$ & $2(\mathrm{WO} / \mathrm{T})$ & \\
\hline \multicolumn{4}{|l|}{ Trial $1(55 \mathrm{~d})^{\mathrm{c}}$} \\
\hline Initial weight, $\mathrm{kg}$ & 22.92 & 23.21 & \\
\hline Average daily gain, $\mathrm{kg}$ & .65 & .60 & \\
\hline Average daily feed intake, $\mathrm{kg}$ & 1.62 & 1.71 & \\
\hline Feed to gain ratio & 2.49 & 2.85 & \\
\hline \multicolumn{4}{|l|}{ Trial $2(55 d)^{d}$} \\
\hline Initial weight, $\mathrm{kg}$ & 28.78 & 28.80 & \\
\hline Average daily gain, $\mathrm{kg}$ & .73 & .72 & \\
\hline Average daily feed intake, $\mathrm{kg}$ & 2.00 & 2.03 & \\
\hline Feed to gain ratio & 2.73 & 2.81 & \\
\hline \multicolumn{4}{|l|}{ Combined } \\
\hline Initial weight, $\mathrm{kg}$ & 25.85 & 26.00 & \\
\hline Average daily gain, $\mathrm{kg}^{\text {ef }}$ & .69 & .66 & 6.76 \\
\hline Average daily feed intake, $\mathrm{kgfg}$ & 1.81 & 1.87 & 7.10 \\
\hline Feed to gain ratio eh & 2.62 & 2.83 & 5.66 \\
\hline
\end{tabular}

${ }^{a} \mathrm{~W} / \mathrm{T}=$ with tallow; $\mathrm{WO} / \mathrm{T}=$ without tallow; 25 pens of 10 pigs/pen for each treatment.

${ }^{\mathrm{b}}$ Coefficient of variation.

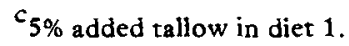

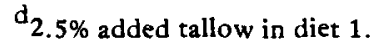

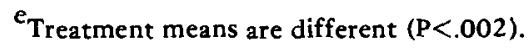

${ }^{f}$ MOF (or fat level) $\times$ treatment interaction $(P<.001)$.

$\mathrm{g}_{\text {Treatment means are different }(}(\mathrm{P}<.02)$.

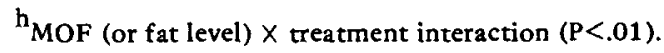

An observation made during trial 1 was the aggressive behavior of pigs fed the diet without tallow. In the building in which this diet was fed, 27 pigs were bitten either on the previously docked tails (19 pigs) or above the hocks (eight pigs). Eight out of 19 pigs had no tails left and most of them were severely bitten. In contrast, only one mild case of tail biting was observed in pigs fed the diet containing tallow. The reason for the difference in the pigs' aggressiveness is not clear. The possible benefit of dietary fat (Fritschen and Peo, 1979) and adverse effect of dusty conditions in the swine buildings (Fritschen and Hogg, 1983) upon the aggressive behavior of pigs have been suggested.

Aerial Dust Concentrations Without Auger Running. The results of temperature, relative humidity and animal activity recordings during the sampling of aerial dust concentration without the feed distribution auger running are summarized in table 3 . The values for temperature and relative humidity are the average of two reading per sampling period. There was little difference in temperature, relative humidity or animal activities between the two buildings. The data for these three factors indicated that their effects on aerial dust concentration were similar for both buildings. These are important factors that influence the aerial dust levels in the animal environment. It has been suggested that the activity of pigs is the major cause of aerial dust suspension (Bundy and Hazen, 1975; Honey and McQuitty, 1979), and other factors such as relative humidity, temperature and ventilation rates modify the levels of dust suspended in the atmosphere of swine-house air (Honey and McQuitty, 1979).

The effects of dietary tallow on aerial dust levels without the feed auger running are presented in table 4. Although the particles were visible, the amount of dust collected was insufficient to be detected by the instrument used in the initial samplings (prestudy periods). A building effect $(P<.05)$ was observed for dust particles of the size that were collected on stage 2 . The reason for the difference is not apparent. Addition of $5 \%$ tallow to the diet reduced aerial 
TABLE 3. TEMPERATURE (T), RELATIVE HUMIDITY (RH) AND ANIMAL ACTIVITY (AA) DURING THE SAMPLING OF AERIAL DUST CONCENTRATIONS

WITHOUT THE FEED AUGER RUNNING (TRIALS 1 AND 2)

\begin{tabular}{|c|c|c|c|c|c|c|c|c|c|c|c|c|c|}
\hline \multirow[b]{4}{*}{ Sampling } & \multirow{4}{*}{$\begin{array}{l}\text { Criteria: } \\
\text { Building: }\end{array}$} & \multicolumn{12}{|c|}{ Trial } \\
\hline & & \multicolumn{6}{|c|}{1} & \multicolumn{6}{|c|}{2} \\
\hline & & \multicolumn{2}{|c|}{$\mathrm{T}(\mathrm{C})$} & \multicolumn{2}{|c|}{ RH (\%) } & \multicolumn{2}{|c|}{$\mathbf{A A}^{\mathrm{a}}$} & \multicolumn{2}{|c|}{$T(C)$} & \multicolumn{2}{|c|}{ RH (\%) } & \multicolumn{2}{|c|}{$\mathrm{AA}^{\mathrm{a}}$} \\
\hline & & $1^{b}$ & 2 & $1^{b}$ & 2 & $1^{b}$ & 2 & 1 & $2^{b}$ & 1 & $2^{b}$ & 1 & $2^{b}$ \\
\hline 1 & & 18 & 17 & 70 & 69 & A & $\mathbf{Q}$ & 17 & 19 & 58 & 62 & VA & VA \\
\hline 2 & & 23 & 21 & 66 & 70 & VA & VA & 22 & 20 & 61 & 69 & A & A \\
\hline 3 & & 20 & 21 & 71 & 74 & $\mathbf{Q}$ & $\mathbf{Q}$ & 19 & 19 & 58 & 68 & A & A \\
\hline 4 & & 17 & 18 & 70 & 71 & $\mathbf{A}$ & $\mathbf{A}$ & 22 & 22 & 58 & 69 & A & A \\
\hline 5 & & 19 & 20 & 72 & 74 & A & A & 19 & 19 & 66 & 60 & $\mathbf{A}$ & $\mathbf{A}$ \\
\hline 6 & & 18 & 19 & 62 & 64 & $\mathbf{A}$ & $\mathbf{Q}$ & 19 & 20 & 56 & 56 & $\mathbf{A}$ & $\mathbf{A}$ \\
\hline 7 & & 16 & 19 & 60 & 64 & $\mathbf{Q}$ & $\mathbf{A}$ & 19 & 20 & 53 & 52 & A & A \\
\hline 8 & & & & & & & & 19 & 21 & 64 & 66 & $\mathbf{A}$ & A \\
\hline
\end{tabular}

${ }^{a} Q=$ quiet; $A$ = active; $V A=$ very active.

${ }^{b}$ Diet containing added tallow was used.

TABLE 4. EFFECT OF DIETARY TALLOW ON AERIAL DUST CONCENTRATIONS WITHOUT THE FEED AUGER RUNNING IN MOF BUILDINGS (TRIALS 1 AND 2)

\begin{tabular}{|c|c|c|c|}
\hline \multirow[b]{2}{*}{ Item } & \multicolumn{2}{|c|}{ Dietb } & \multirow[b]{2}{*}{$\mathrm{SEC}^{\mathrm{C}}$} \\
\hline & $1(W / T)$ & $2(\mathrm{WO} / \mathrm{T})$ & \\
\hline & & & \\
\hline \multicolumn{4}{|l|}{ Trial 1} \\
\hline Stage 1 & 7.07 & 12.88 & \\
\hline 2 & 2.96 & 6.37 & \\
\hline 3 & .22 & .89 & \\
\hline 4 & .03 & .07 & \\
\hline Total & 10.28 & 20.21 & \\
\hline \multicolumn{4}{|l|}{ Trial 2} \\
\hline Stage 1 & 10.56 & 13.00 & \\
\hline 2 & 4.42 & 5.94 & \\
\hline 3 & .59 & .94 & \\
\hline 4 & .18 & .16 & \\
\hline Total & 15.76 & 20.05 & \\
\hline \multicolumn{4}{|l|}{ Combined } \\
\hline Stage $1^{d}$ & 8.89 & 12.95 & 1.49 \\
\hline $2^{\text {ef }}$ & 3.73 & 6.12 & .56 \\
\hline $3^{e}$ & .42 & .92 & .12 \\
\hline 4 & .11 & .11 & .04 \\
\hline Totalg & 13.20 & 20.12 & 2.17 \\
\hline
\end{tabular}

${ }^{a}$ Dust particle sizes: stage $1,14 \mu \mathrm{m}$; stage $2,4 \mu \mathrm{m}$; stage $3,1.5 \mu \mathrm{m}$; stage $4, .4 \mu \mathrm{m}$.

$\mathrm{b}_{\mathrm{W} / \mathrm{T}}=$ with tallow; $\mathrm{WO} / \mathrm{T}=$ without tallow.

$\mathbf{c}_{\text {Standard error of the mean. }}$

$\mathrm{d}_{\text {Treatment means are different }}(\mathrm{P}=.10)$.

$\mathrm{E}$ Treatment means are different $(\mathrm{P}<.02)$.

${ }^{f}$ Building effect $(P<.05)$.

$\mathrm{g}_{\text {Treatment means are different }}(\mathrm{P}=.06)$. 
dust concentrations in all size classes in trial 1. Total dust concentration was $10.28 \mathrm{mg} / \mathrm{m}^{3}$ for Building 1 and $20.21 \mathrm{mg} / \mathrm{m}^{3}$ for Building 2 . This was a $49 \%$ reduction of aerial dust in the atmosphere of the swine-house air in which diet containing tallow had been fed. Similar results were observed in trial 2, except for a lower reduction of aerial dust when only $2.5 \%$ tallow was added to the diet (49\%, trial 1 vs $21 \%$, trial 2).

The mean concentrations of aerial dust in the buildings, where diet 2 (no added tallow) was fed, were similar in both trials. However, the dust levels in the buildings in which diet 1 ( 5 and $2.5 \%$ added tallow) was fed, depended on the level of tallow in the diet. Although a direct comparison was not possible, the results indicate that adding $5 \%$ tallow to the diet is superior to adding $2.5 \%$ for reducing swinehouse dust.

A large proportion of the mass of dust particles was collected at stage $1(14 \mu \mathrm{m})$. These particles are generally considered to be too large to penetrate into the lower respiratory tract (Jericho, 1968; Curtis, 1972; Cermak and Ross, 1978; Feddes and McQuitty, 1983). Thus this size-class is not critical as far as respiratory disorders are concerned. However, these particles do contribute to the deterioration of buildings and equipment (Bundy et al., 1974; Owen, 1982). Also these particles are primarily responsible for transporting obnoxious odors (Honey and McQuitty, 1976; Cermak and Ross, 1978). The possible adverse effects of swine-house odor upon performance of sows have been noted (Curtis, 1981). Furthermore, the inhalation and deposition of animal protein of this size class into the nose, trachea or bronchi can cause allergic reactions and may lead to asthma in humans (Muir, 1983), and plant spores may cause rhinitis in swine when deposited in the nose (Cermak and Ross, 1978).

Although most of the dust collected was 14 $\mu \mathrm{m}$ or larger, it is conceivable that the aerodynamics size of less than $4 \mu \mathrm{m}$ accounts for a majority of the number of dust particles. This contention coincides with the reports of Bundy and Hazen (1975) and Owen (1982). Particles of $<5 \mu \mathrm{m}$ have a greater impact than larger particles on respiratory structures because of their ability to penetrate into the deeper respiratory system (Jericho, 1968; Bundy and Hazen, 1975; Curtis et al., 1975a; Honey and McQuitty, 1979; Owen, 1982). Particles of this size have both direct adverse effects (Curtis,
1972; Cermak and Ross, 1978) and indirect effects on swine by acting as a carrier of potentially harmful gases and microorganisms (Harry, 1964; Martin and Willoughby, 1972; Cermak and Ross, 1978; Curtis, 1981; Owen, 1982; Feddes and McQuitty, 1983).

In trial 2, the collection of pig weights and feed consumption data was discontinued and the buildings were operated without any restrictions after the eighth week. Because it was spring and temperatures were becoming warmer, doors were opened as necessary to maintain optimum conditions for the pigs. The aerial dust concentrations without the auger running were measured for an additional 4 wk (2 samplings/wk). The mean total concentrations were $8.12 \mathrm{mg} / \mathrm{m}^{3}$ for Building 2 and $10.40 \mathrm{mg} / \mathrm{m}^{3}$ of air for Building 1 . These concentrations were approximately $50 \%$ lower than dust concentrations obtained when buildings were completely closed, and were comparable with the threshold limit value for inert dust established by the American Conference of Governmental Industrial Hygienists (Curtis, 1981). However, this standard is for the workers occupying contaminated space for $40 \mathrm{~h} / \mathrm{wk}$, whereas confined animals confront the same environment almost continuously. Considering the fact that the pigs face other potentially harmful air factors simultaneously (Curtis, 1972), these results might indicate that the problems of swine-house dust continue to exist even when MOF buildings are opened. Nevertheless, the reduction of aerial dust concentrations with dietary inclusion of tallow was similar to the first phase of a trial when the buildings were closed during the measurements ( 21 vs $22 \%$ ).

Aerial Dust Concentrations With Auger Running. The summary of aerial dust concentrations with the feed auger running is shown in table 5. The results were similar for both trials. Addition of tallow to the diets of growingfinishing swine reduced the concentration of dust in all size classes. Overall total dust concentrations were $17.98 \mathrm{mg} / \mathrm{m}^{3}$ for the buildings in which diets that contained tallow were fed and $92.35 \mathrm{mg} / \mathrm{m}^{3}$ for the buildings in which diets did not contain tallow. The dust generated during the filling of feeders is a major source of total amount of dust in buildings.

Settled Dust. The results of settled dust measurements in trial 1 are summarized in table 6. The amounts of settled dust were different throughout the locations between the two 
TABLE 5. EFFECT OF DIETARY TALLOW ON AERIAL DUST CONCENTRATIONS WITH THE FEED AUGER RUNNING IN MOF BUILDINGS (TRIALS 1 AND 2)8

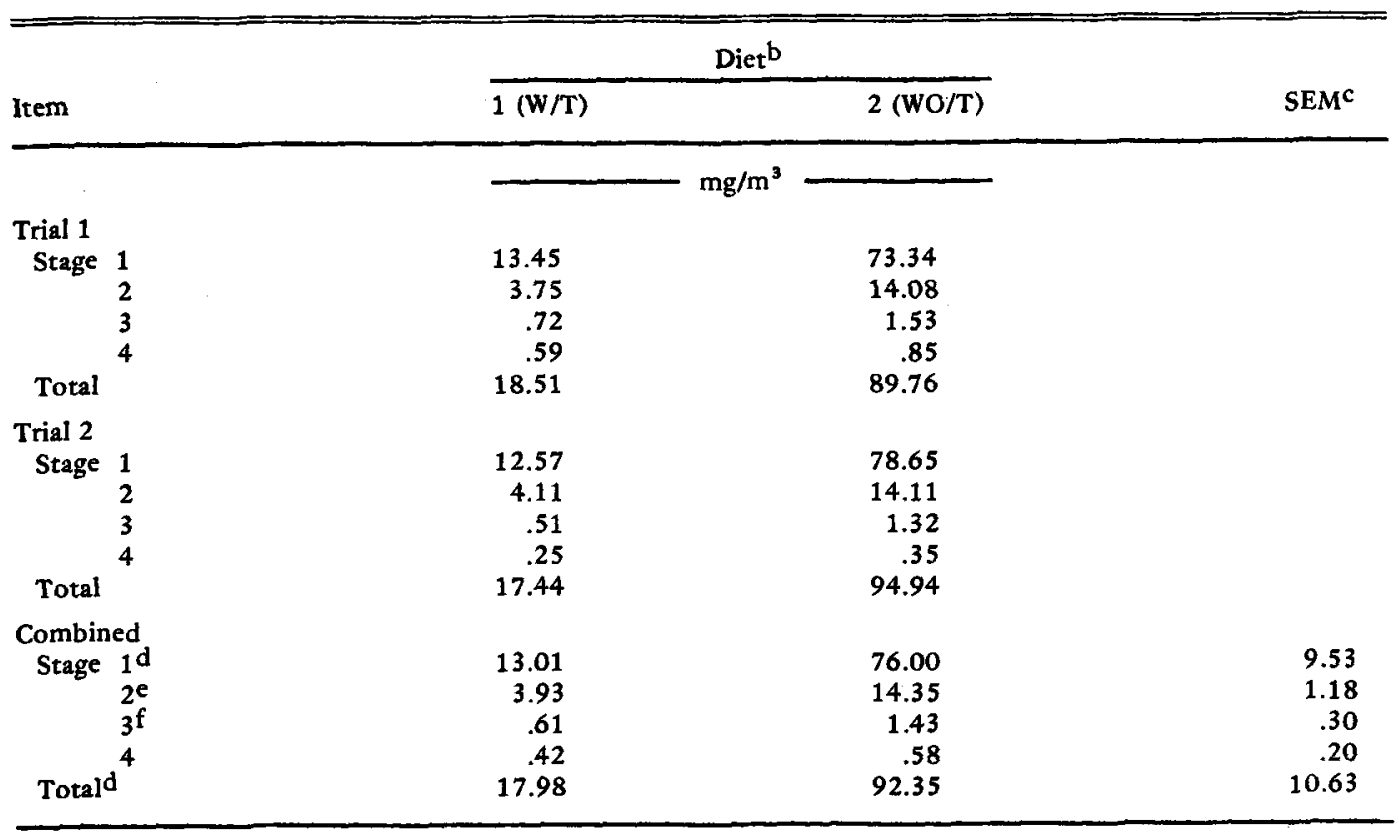

${ }^{a}$ Dust particle sizes: stage $1,14 \mu \mathrm{m}$; stage $2,4 \mu \mathrm{m}$; stage $3,1.5 \mu \mathrm{m}$; stage $4, .4 \mu \mathrm{m}$.

${ }^{\mathrm{b}} \mathbf{W} / \mathrm{T}=$ with tallow; $\mathbf{W O} / \mathrm{T}=$ without tallow.

$c_{\text {Standard error of the mean. }}$

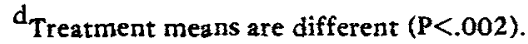

e Treatment means are different $(P<.001)$.

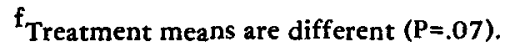

buildings. The dust concentration in Building 1 was 41 and $39 \%$ less for the first and second sample sets than was present in Building 2 . Overall, the addition of $5 \%$ tallow to the diet resulted in a $41 \%$ reduction $(\mathrm{P}<.001)$ of settled dust in the MOF building. Settled dust was analyzed for crude protein content (table 6) and also examined microscopically. The results indicated that the dust collected was mainly feed dust.

In trial 2, the settled dust samples were lost during the eighth week due to strong wind. The

TABLE 6. EFFECT OF DIETARY TALLOW ON THE AMOUNT OF SETTLED DUST AND IT'S CRUDE PROTEIN CONTENT IN MOF BUILDINGS (TRIAL 1)

\begin{tabular}{|c|c|c|c|c|c|c|c|}
\hline \multirow[b]{2}{*}{ Sample set } & \multirow[b]{2}{*}{$\operatorname{Diet}^{\mathbf{a}}$ : } & \multicolumn{3}{|c|}{ Settled dust (g) } & \multicolumn{3}{|c|}{ Crude protein $(\%)^{\mathrm{b}}$} \\
\hline & & $1(W / T)$ & $2(\mathrm{WO} / \mathrm{T})$ & $\mathrm{CV}^{\mathrm{c}}, \%$ & $1(\mathrm{~W} / \mathrm{T})$ & $2(\mathrm{WO} / \mathrm{T})$ & $\mathrm{CV}^{\mathrm{c}}, \%$ \\
\hline $\begin{array}{l}1(53 d)^{d} \\
2(30 d)^{d} \\
\text { Average } d\end{array}$ & & $\begin{array}{l}2.21 \\
2.02 \\
2.11\end{array}$ & $\begin{array}{l}3.77 \\
3.32 \\
3.55\end{array}$ & $\begin{array}{l}7.82 \\
5.67 \\
6.31\end{array}$ & 18.06 & 16.17 & 2.20 \\
\hline
\end{tabular}

\footnotetext{
${ }^{\mathrm{a}} \mathrm{W} / \mathrm{T}=$ with tallow; $\mathrm{WO} / \mathrm{T}=$ withour tallow.

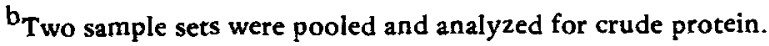

${ }^{c}$ Coefficient of variation.

$\mathrm{d}_{\text {Treatment means are different }}(\mathrm{P}<.001)$.
} 
TABLE 7. EFPECT OF DIETARY TALLOW ON LUNG LESIONS OF PIGS REARED IN MOF BUILDINGS (TRIALS 1 AND 2)

\begin{tabular}{|c|c|c|c|c|c|c|}
\hline \multirow[b]{2}{*}{ Score } & Trial: & 1 & \multicolumn{2}{|c|}{2} & \multicolumn{2}{|c|}{ Combined } \\
\hline & Diet: $1^{b}(W / T)$ & $2(\mathrm{WO} / \mathrm{T})$ & $1^{c}(W / T)$ & 2 (WO/T) & $1(\mathrm{~W} / \mathrm{T})$ & $2(\mathrm{WO} / \mathrm{T})$ \\
\hline 0 & 8 & 4 & 10 & 5 & 18 & 9 \\
\hline 1 & 18 & 14 & 2 & 3 & 20 & 17 \\
\hline 2 & 4 & 3 & 7 & 4 & 11 & 7 \\
\hline 3 & 0 & 3 & 9 & 10 & 9 & 13 \\
\hline 4 & 0 & 2 & 4 & 6 & 4 & 8 \\
\hline 5 & o & 0 & 1 & 0 & 1 & 0 \\
\hline 6 & o & 0 & 0 & 2 & 0 & 2 \\
\hline Total & 30 & 26 & 33 & 30 & $\overline{63}$ & 56 \\
\hline
\end{tabular}

${ }^{2}$ Higher values assigned for greater severity of lung lesions.

$\mathrm{b}_{5 \%}$ tallow added to the diet; $\mathrm{W} / \mathrm{T}=$ with tallow; $\mathrm{WO} / \mathrm{T}=$ without tallow.

$c_{2.5 \%}$ tallow added to the diet.

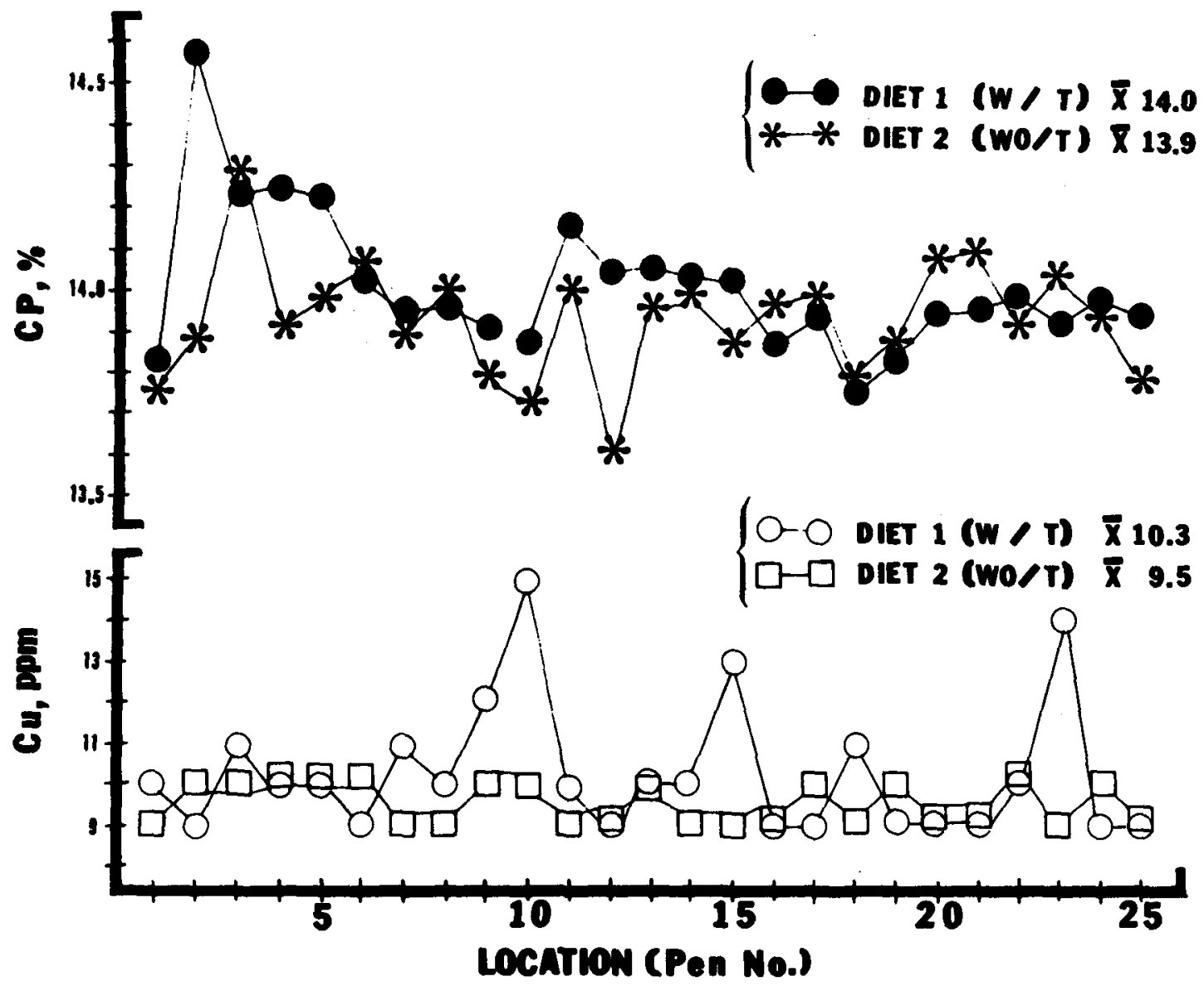

Figure 2. Effect of dietary tallow on crude protein (CP) and $\mathrm{Cu}$ content of diets along the length of the automated "Flex-auger" feed distribution system (trial 1). A slope of CP in diet 1 was statistically different than 0 $(\mathrm{P}<.05)$. W/T: with 5\% added tallow; WO/T: without added tallow. 
petri dishes were replaced with 12 sampling jars (same diameter as petri dishes) in each building and dust was collected for $27 \mathrm{~d}$. The buildings were not completely closed during this phase of the trial. Therefore, factors such as wind blowing through the buildings may have affected dust accumulation in the jars. The mean amounts of settled dust were $.81 \mathrm{~g}$ for the building in which a diet containing $2.5 \%$ tallow was fed and $.89 \mathrm{~g}$ for the building in which a diet containing no tallow was fed $(9.8 \%$ difference).

Respiratory Structures. The results of lung examinations at the end of the trials are presented in table 7 . No relationship was found ( $P>.10)$ between the two diets and lung lesion scores, but the overall incidence of lung lesions was higher in pigs fed the diets without tallow (83.9 vs $71.4 \%$ ). Also, there was a tendency for pigs fed the diet without tallow to have more severe forms of lung lesions than those fed the diet with tallow.

The lungs that showed severe lesions were examined by light microscope and cultured for bacterial pathogens. The lesions were the same for each of the lungs examined and consisted of a chronic pneumonia with changes characteristic of Mycoplasma hyopneumoniae infection. The culture of all lungs yielded Pasteurella multocida.

There was no evidence of structural alterations in the snouts of the pigs in trial 1, but two pigs fed the diet with tallow had turbinate deviations of $>6 \mathrm{~mm}$ in trial 2 . The turbinates of all pigs, except those two, were classified as "normal."

Feed Particle Separation. The criteria of response for determining whether any mechanical separation of feed nutrients was affected by adding tallow were crude protein, $\mathrm{Ca}, \mathrm{P}$ and $\mathrm{Cu}$ content of the diets. The results are summarized in figures 2 and 3 , and table 8 . Each value represents the average of three sets of feed samples taken during the study.

In trial 1 , although diets were formulated to contain $15 \%$ crude protein, the average analyzed value was approximately $14 \%$ for both diets.

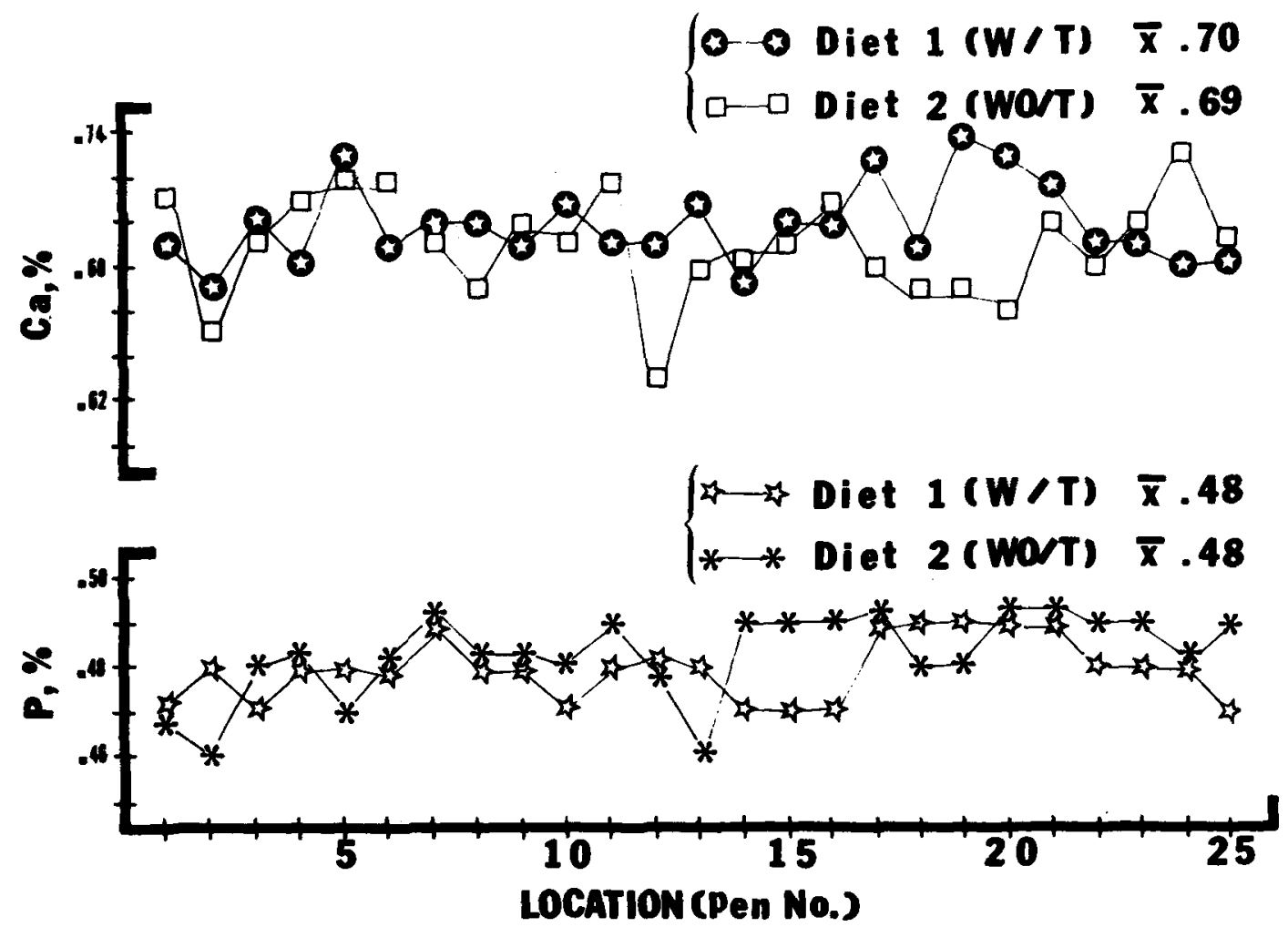

Figure 3. Effect of dietary tallow on $\mathrm{Ca}$ and $\mathrm{P}$ content of diets along the length of the automated "Flexauger" feed distribution system (trial 1). A slope of $P$ in diet 2 was statistically different than 0 ( $P<.05$ ). Slopes of $P$ in the two diets were different $(P<.05)$. W/T: with $5 \%$ added tallow; WO/T: without added tallow. 
TABLE 8. EFFECT OF DIETARY TALLOW ON NUTRIENT CONTENT OF DIETS ALONG THE LENGTH OF THE AUTOMATED "FLEX-AUGER" DISTRIBUTION SYSTEM (TRIAL 2)

\begin{tabular}{|c|c|c|c|c|c|c|c|c|}
\hline \multirow[b]{3}{*}{$\begin{array}{l}\text { Pen num } \\
\text { ber }\end{array}$} & \multicolumn{8}{|c|}{ Criteria } \\
\hline & \multicolumn{2}{|c|}{ CP (\%) } & \multicolumn{2}{|c|}{$\mathrm{Cu}$ (ppm) } & \multicolumn{2}{|c|}{$\mathrm{Ca}(\%)$} & \multicolumn{2}{|c|}{ P (\%) } \\
\hline & $\operatorname{Diet}^{b}:(W / T)$ & $\begin{array}{l}2 \\
(W O / T)\end{array}$ & $\begin{array}{l}1 \\
(W / T)\end{array}$ & 2 & $\begin{array}{l}1 \\
(W / T)\end{array}$ & $\begin{array}{l}2 \\
\text { (WO/T) }\end{array}$ & $\begin{array}{l}1 \\
(W / T)\end{array}$ & $\begin{array}{l}2 \\
\text { (WO/T) }\end{array}$ \\
\hline 1 & 15.39 & 15.44 & 13 & 13 & .72 & .75 & .57 & .59 \\
\hline 2 & 15.44 & 15.27 & 13 & 13 & .72 & .63 & .57 & .56 \\
\hline 3 & 15.42 & 15.41 & 13 & 13 & .71 & .70 & .57 & .59 \\
\hline 4 & 15.29 & 15.34 & 13 & 13 & .75 & .69 & .56 & .58 \\
\hline 5 & 15.31 & 15.30 & 13 & 12 & .74 & .68 & .56 & .56 \\
\hline 6 & 15.33 & 15.42 & 13 & 12 & .75 & .70 & .56 & .57 \\
\hline 7 & 15.40 & 15.48 & 13 & 13 & .72 & .68 & .56 & .57 \\
\hline 8 & 15.41 & 15.39 & 13 & 11 & .73 & .66 & .55 & .55 \\
\hline 9 & 15.25 & 15.32 & 13 & 13 & .73 & .67 & .55 & .56 \\
\hline 10 & 15.28 & 15.37 & 13 & 13 & .75 & .69 & .57 & .57 \\
\hline 11 & 15.20 & 15.38 & 12 & 13 & .69 & .69 & .54 & .56 \\
\hline 12 & 15.04 & 15.55 & 13 & 13 & .71 & .69 & .54 & .55 \\
\hline 13 & 15.40 & 15.37 & 13 & 13 & .67 & .71 & .55 & .56 \\
\hline 14 & 15.44 & 15.78 & 13 & 13 & .71 & .71 & .53 & .57 \\
\hline 15 & 15.64 & 15.61 & 13 & 13 & .71 & .65 & .55 & .55 \\
\hline 16 & 15.52 & 15.51 & 13 & 12 & .72 & .64 & .55 & .54 \\
\hline 17 & 15.40 & 15.80 & 13 & 12 & .72 & .66 & .54 & .56 \\
\hline 18 & 15.39 & 15.58 & 13 & 13 & .69 & .67 & .54 & .55 \\
\hline $\begin{array}{l}10 \\
19\end{array}$ & 15.29 & $\begin{array}{l}15.00 \\
15.49\end{array}$ & 13 & 12 & .69 & .64 & .54 & .55 \\
\hline 20 & 15.43 & 15.85 & 13 & 13 & .72 & .67 & .55 & .55 \\
\hline 21 & 15.39 & 15.56 & 13 & 13 & .70 & .63 & .54 & .53 \\
\hline 22 & 15.36 & 15.49 & 14 & 12 & .72 & .61 & .54 & .54 \\
\hline 23 & 15.25 & 15.50 & 14 & 13 & .71 & .60 & .53 & .53 \\
\hline 24 & 15.36 & 15.56 & 12 & 15 & .69 & .63 & .54 & .53 \\
\hline 25 & 15.47 & 15.53 & 12 & 13 & .70 & .64 & .55 & .54 \\
\hline Mean & 15.36 & 15.49 & 13 & 13 & .71 & .67 & .55 & .56 \\
\hline Slope & .002 & .012 & -.002 & .019 & -.001 & -.003 & -.001 & $-.002 *$ \\
\hline
\end{tabular}

"Values indicate the average of three sampling periods.

${ }^{\mathrm{b}} \mathrm{W} / \mathrm{T}=$ with tallow; $\mathbf{W O} / \mathrm{T}=$ without tallow.

"Slope is different than $0(\mathrm{P}<.01)$.

There was a trend for a linear decrease in crude protein content along the distribution system for the diet that contained tallow $(P<.05)$. This was mainly due to the higher crude protein values of the second sample set. Because the difference between the highest and lowest value was only $.8 \%$, and the rest of the values were relatively consistent, this trend may not have any biological significance. Feed samples from three pens contained a relatively high $\mathrm{Cu}$ content in the diet with tallow. This was also due to the abnormally high values of second sample set $(23,22$ and $23 \mathrm{ppm}$ for pens 10, 15 and 23 , respectively). The copper content of the feed in those three pens in the first and third sample sets was similar to other pens.

Calcium contents of both diets were essentially the same along the distribution system.
There was no difference in the regression coefficients of the two diets for all criteria except $P(P<.05)$. The nutritional significance of this trend is probably minor because the difference between the highest and lowest values of $P$ was only $.03 \%$.

In trial 2 (table 8 ), protein and $\mathrm{Cu}$ contents of both diets were quite similar. The values of $\mathrm{Ca}$ and $\mathrm{P}$ were decreased $(\mathrm{P}<.01)$ toward the end of the feed distribution system for both diets. This was more evident in the $\mathrm{Ca}$ content of the diet without tallow than in the diet with tallow. Again, however, the observed differences were small (although significant) and may not be important from a nutritional standpoint.

It appears that there was very little nutrient separation along the automated feed distribution system used in this study, and that the addition 
of tallow to the diet had neither positive nor negative effects on the nutrient separation.

\section{Trials 3 and 4}

Performance. The effects of dietary tallow on gain, feed intake and feed conversion are presented in table 9. Overall, pigs fed the diet containing $5 \%$ tallow gained faster $(.77$ vs .72 $\mathrm{kg} / \mathrm{d}, \mathrm{P}<.002$ ), consumed less feed ( $2.36 \mathrm{vs}$ $2.46 \mathrm{~kg} / \mathrm{d}, \mathrm{P}<.002$ ) and showed a $10.2 \%$ improvement in F:G (3.09 vs 3.44, P<.001).

Aerial Dust. There was no appreciable difference in temperature, relative humidity or animal activity between the two buildings during the sampling of aerial dust. The effects of tallow on aerial dust concentrations are summarized in figures 4,5 and 6 . The reason for the interactions (figure 6) is not clear. It might be due partly to differences in humidity within (36 to $59 \%$ in trial 3 and 54 to $80 \%$ in trial 4) and between the trials (50\% in trial 3 vs $65 \%$ in trial 4) during the samplings and the problems associated with aerial dust measurement (Honey and McQuitty, 1976). Addition of $5 \%$ tallow to the diet of finishing swine resulted in the reduction of aerial dust concentrations of particle sizes of 14,4 and $1.5 \mu \mathrm{m}$ $(\mathrm{P}<.002)$, and .4 $\mu \mathrm{m}(\mathrm{P}=.07)$ in trial 3. Similar differences were observed in trial 4, except for the magnitude of aerial dust concentrations. The lower aerial dust concentrations in trial 4, compared with trial $3(P<.001)$, might be explained partially by differences in relative humidity. In any event, the reduction of dust levels when the diet contained tallow was apparent regardless of the relative humidity.

Although there are many factors involved, it is rather interesting to note the differences in performance (ADG and ADFI) and aerial dust concentrations between the two trials. The aerial dust concentrations were lower $(P<.001)$ and the performance of pigs was higher $(P<.001)$ in trial 4 than trial 3 . The adverse effects of dust on health of animals and animal attendants have been described previously. Therefore, the lower aerial dust concentrations in trial 4 and the consequent improvement of air quality in the buildings may have been one factor that influenced the pigs' performance.

TABLE 9. EFFECT OF TALLOW ON GAIN AND FEED CONVERSION OF PIGS REARED IN ENVIRONMENTALLY REGULATED BUILDINGS (TRIALS 3 AND 4)

\begin{tabular}{|c|c|c|c|}
\hline \multirow[b]{2}{*}{ Item } & \multicolumn{2}{|c|}{$\operatorname{Diet}^{\mathrm{a}}$} & \multirow[b]{2}{*}{$\mathbf{C V}^{\mathbf{b}}, \%$} \\
\hline & $1(\mathrm{~W} / \mathrm{T})$ & $2(\mathrm{WO} / \mathrm{T})$ & \\
\hline \multicolumn{4}{|l|}{ Trial $3(63 \mathrm{~d})$} \\
\hline Initial weight, $\mathrm{kg}$ & 49.64 & 49.35 & 2.34 \\
\hline Average daily gain, $\mathrm{kg}$ & .68 & .64 & 7.56 \\
\hline Average daily feed intake, $\mathrm{kg}$ & 2.10 & 2.16 & 7.20 \\
\hline Feed to gain ratioc & 3.11 & 3.40 & 2.83 \\
\hline \multicolumn{4}{|l|}{ Trial $4(56 \mathrm{~d})$} \\
\hline Initial weight, $\mathrm{kg}$ & 48.60 & 48.93 & 1.27 \\
\hline Average daily gain, $\mathrm{kgd}$ & .86 & .80 & 6.52 \\
\hline Average daily feed intake, $\mathrm{kg}^{\mathrm{d}}$ & 2.62 & 2.75 & 4.92 \\
\hline Feed to gain ratioc & 3.06 & 3.47 & 4.55 \\
\hline \multicolumn{4}{|l|}{ Combined } \\
\hline Initial weight, $\mathrm{kg}^{\mathrm{e}}$ & 49.12 & 49.14 & 1.34 \\
\hline Average daily gain, $\mathrm{kgfg}$ & .77 & .72 & 5.63 \\
\hline Average daily feed intake, $\mathrm{kg} f g$ & 2.36 & 2.46 & 3.45 \\
\hline Feed to gain ratioc & 3.09 & 3.44 & 3.52 \\
\hline
\end{tabular}

${ }^{\mathrm{a}} \mathrm{W} / \mathrm{T}=$ with tallow; $\mathrm{WO} / \mathrm{T}=$ without tallow; 12 pens of $10 \mathrm{pigs} / \mathrm{pen}$ for each treatment.

${ }^{\mathrm{b}}$ Coefficient of variation.

${ }^{c}$ Treatment means are different $(P<.001)$

$\mathrm{d}_{\text {Treatment means are different }}(\mathrm{P}<.05)$.

Trial effect $(P<.01)$.

$f_{\text {Treatment means are different }(P<.002)}$

g Trial effect $(\mathrm{P}<.001)$. 


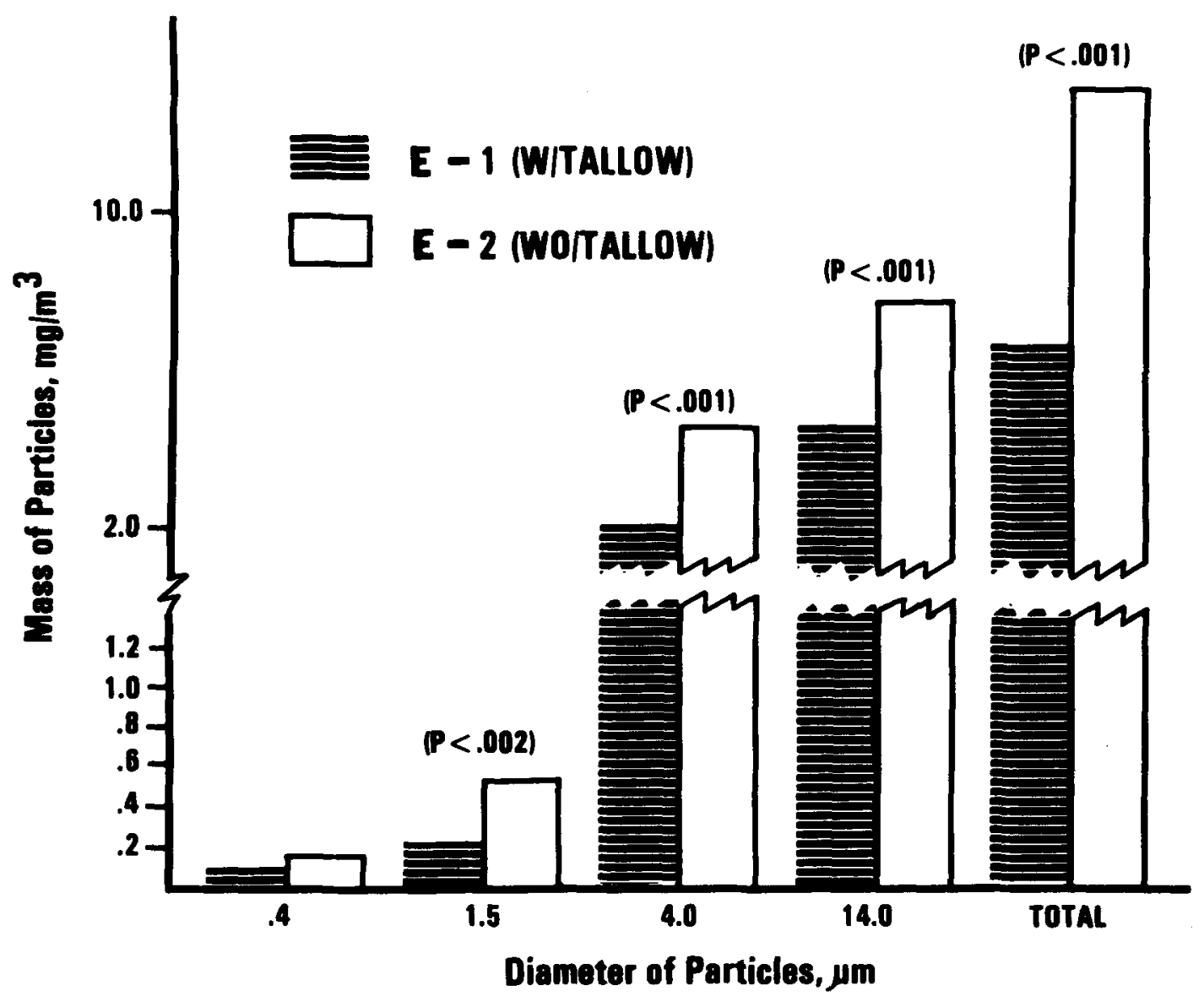

Figure 4. Effect of dietary tallow on aerial dust concentrations in environmentally regulated buildings (trial 3). Parentheses indicate the differences in treatment means. W/Tallow: with tallow; WO/Tallow: without tallow. Standard error of the mean: .02,.4 $\mu \mathrm{m} ; .03,1.5 \mu \mathrm{m} ; .15,4.0 \mu \mathrm{m} ; .13,14.0 \mu \mathrm{m} ; .24$, total.

Settled Dust. The results of the settled dust measurements are presented in table 10 . The amounts of settled dust were different $(\mathrm{P}<.001)$ between the two buildings throughout the locations in both trials 3 and 4 . Addition of $5 \%$ tallow to the diet of finishing swine reduced settled dust by 23 and $40 \%$. The amounts of settled dust were lower in trial 4 (mean amounts of 2.18 and $2.84 \mathrm{~g}$ for trial 3 vs 1.12 and $1.87 \mathrm{~g}$ for trial 4 for buildings 1 and 2, respectively, $\mathrm{P}<.001)$. The differences in amount of settled dust might be due to the differences in relative humidities ( 41 to $55 \%$ in trial 3 vs 51 to $77 \%$ in trial 4), which might also account for the treatment $x$ trial interaction $(P<.01)$. Although the dust particles are less likely to become airborne in a humid environment, they may absorb water vapor from the air once they are suspended. Heavier particles settle out quickly, rather than circulating as atmospheric dust (Honey and McQuitty, 1979).

Crude protein analysis of settled dust showed higher values for the building in which the diet containing $5 \%$ tallow was fed (table $10)$. The reason for this might be differences in the composition of swine-house dust. Swinehouse dust consists of particles of solid matter such as soil, feed, animal hair, skin debris and dried fecal material (Curtis, 1972; Cermak and Ross, 1978; Feddes and McQuitty, 1983). If the feed dust was reduced by the addition of fat to the diets, then the crude protein value should increase because of increased proportion of hair and skin debris (which are high in crude protein content) in the swine-house dust. Illustrated in figure 7 is the relationship between aerial dust concentrations and crude protein content of settled dust. As the aerial 


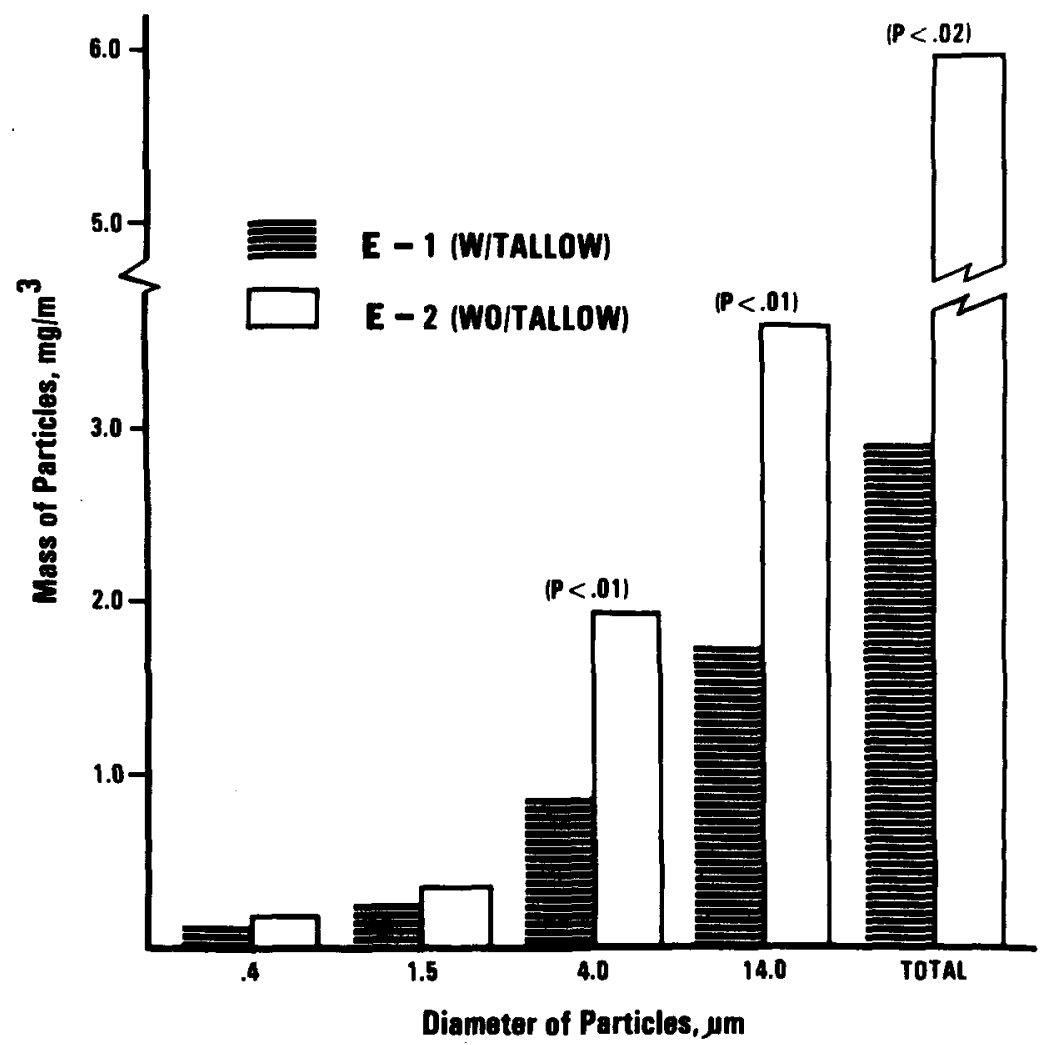

Figure 5. Effect of dietary tallow on aerial dust concentrations in environmentally regulated buildings (trial 4). Parentheses indicate the differences in treatment means. W/Tallow: with tallow; WO/Tallow: without tallow. Standard error of the mean: .02, .4 $\mu \mathrm{m} ; .03,1.5 \mu \mathrm{m}, .14,4.0 \mu \mathrm{m} ; .42,14.0 \mu \mathrm{m} ; .10$, total.

dust concentrations decrease, the crude protein values increase $(r=-.87 ; \mathrm{P}<.05)$. These results, along with microscopic examinations of collected dust, suggest that the swine-house dust was mostly feed dust. This conclusion is similar to the findings of Curtis et al. (1975b) and Honey and McQuitty (1979).

Respiratory Structures. The results of the lung examinations at the end of the trials are presented in table 11 . Most of the lung samples, $90 \%$ for diet 1 and $78 \%$ for diet 2 , showed various degrees of lung lesions in trial 3. Overall, there was no relationship between the two diets and lung lesion scores. However, a difference $(\mathrm{P}<.01)$ between the two diets for score 1 was detected by the funcat procedure. A little more than one-half of the pigs fed the diet with tallow, which had various degrees of lung lesions, belong to the category of very mild lesions. This is reflected in the tendency for pigs fed the diet without tallow to have more severe forms of lung lesions (score 2 through 5 ) than those fed the diet with tallow (66 vs $39 \%$ ). This trend is similar to an observation made in trial 1. Similar results were not observed in trial 4.

Light microscopic examination of the lung lesions showed variable numbers of polymorphonuclear inflammatory cells, mononuclear cells and macrophages. Dense lymphocytic cuffs were surrounding most bronchi, bronchioles and branches of the pulmonary artery. Occasionally, formation of large lymphocytic follicles was seen in these areas. Lesions observed were typical of those seen in Mycoplasma hyopneumoniae infection complicated with secondary invasion of bacterial organisms. Cultures of each lung yielded Pasturella multocida.

Most of the turbinates examined showed no structural alteration $(67 \%$ for the diet with tallow and $70 \%$ for the diet without tallow, $\mathrm{P}>.10)$. Pigs fed the diet with tallow, which showed abnormal turbinates in trial 3, had 


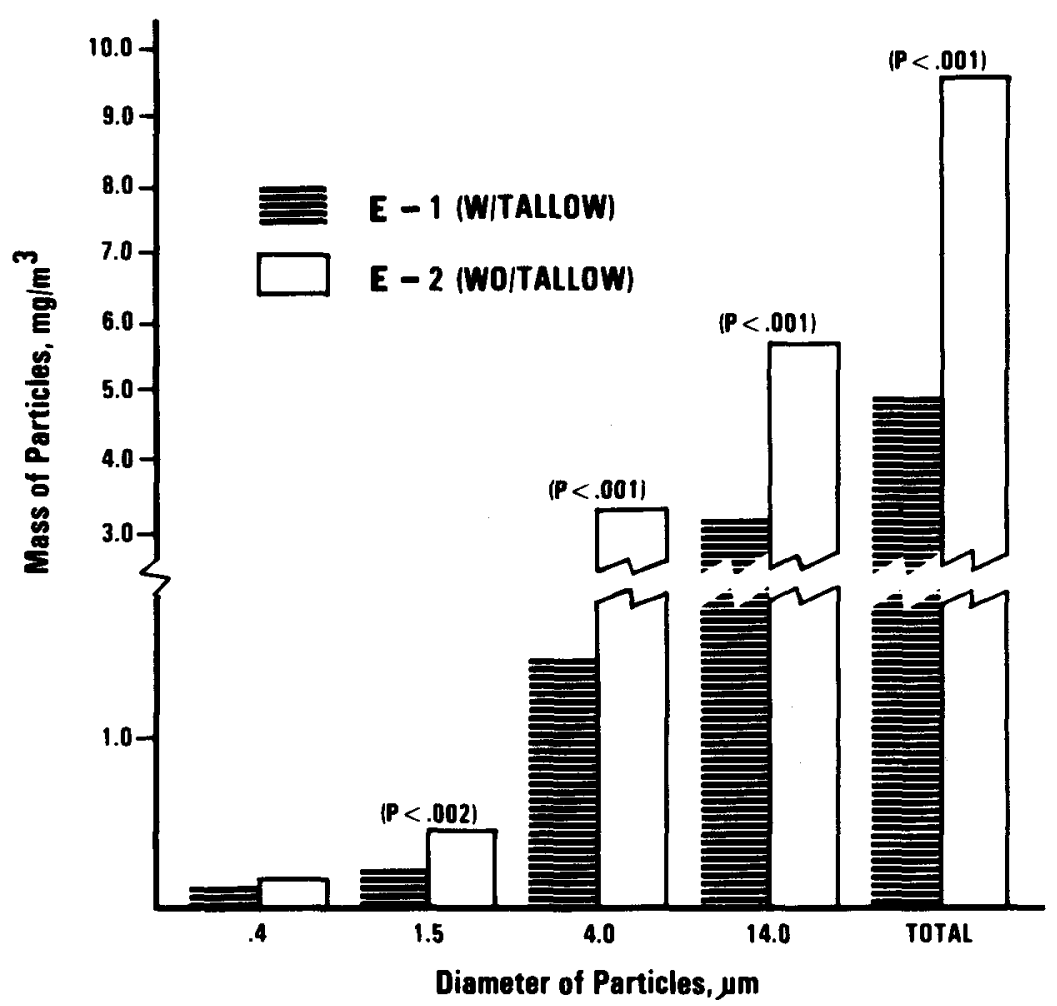

Figure 6. Effect of dietary tallow on aerial dust concentrations in environmentally regulated buildings (trials 3 and 4 combined). Parentheses indicate the differences in treatment means. Trial effect: $1.5 \mu \mathrm{m}(P<.05) ; 4.0$ $\mu \mathrm{m}, 14.0 \mu \mathrm{m}$ and total $(\mathrm{P}<.001)$. Treatment $X$ trial interaction: $4.0 \mu \mathrm{m}, 14 \mu \mathrm{m}$ and total $(\mathrm{P}<.05)$. Sampling days $X$ trial interaction: $4.0 \mu \mathrm{m}, 14.0 \mu \mathrm{m}$ and total $(\mathrm{P}<.05)$. Treatment $X$ sampling days interaction: .4 $\mu \mathrm{m}(P<.05)$. W/Tallow: with tallow; WO/Tallow: without tallow. Standard error of the mean: $.01, .4 \mu \mathrm{m} ; .02,1.5 \mu \mathrm{m} ; .10$, $4.0 \mu \mathrm{m} ; .11,14.0 \mu \mathrm{m} ; .19$, total.

relatively lower lung lesion scores (table 11 ), whereas lungs of pigs fed the diet without tallow, that had abnormal turbinates, were classified into the relatively high lung lesion scores in trial 3. The nasal passages serve to filter, humidify and warm inspired air. The design of the turbinates create a swirling motion to the inspired air so that most particles larger than $5 \mu \mathrm{m}$ impinge upon the mucus blanket in the rostral portion of the nasal

TABLE 10. EFFECT OF TALLOW ON SETTLED DUST LEVELS AND CRUDE PROTEIN CONTENT IN ENVIRONMENTALLY REGULATED BUILDINGS (TRIALS 3 AND 4)

\begin{tabular}{|c|c|c|c|c|c|c|c|}
\hline \multirow[b]{2}{*}{ Item } & \multirow[b]{2}{*}{ Buildinga: } & \multicolumn{3}{|c|}{ Settled dust (g) } & \multicolumn{3}{|c|}{ Crude protein (\%) } \\
\hline & & $1(\mathrm{~W} / \mathrm{T})$ & $2(\mathrm{WO} / \mathrm{T})$ & $\mathrm{CV}^{\mathrm{b}}, \%$ & $1(\mathrm{~W} / \mathrm{T})$ & $2(\mathrm{WO} / \mathrm{T})$ & $\mathrm{CV}^{\mathrm{b}}, \%$ \\
\hline \multirow{3}{*}{\multicolumn{2}{|c|}{$\begin{array}{l}\text { Trial } 3^{c} \\
\text { Trial } 4^{c} \\
\text { Combinedcde }\end{array}$}} & 2.18 & 2.84 & 5.95 & 23.53 & 21.78 & 1.92 \\
\hline & & 1.12 & 1.87 & 16.11 & 25.88 & 22.55 & 2.31 \\
\hline & & 1.65 & 2.33 & 9.61 & 24.71 & 22.19 & 2.58 \\
\hline
\end{tabular}

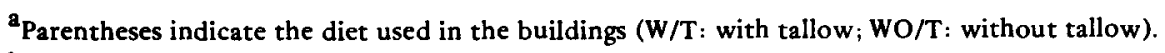

${ }^{b}$ Coefficient of variation.

${ }^{c}$ Treatment means are different $(P<.001)$.

$d_{\text {Trial effect }}(P<.001)$.

e Treatment $\times$ trial interaction $(P<.01)$.
} 


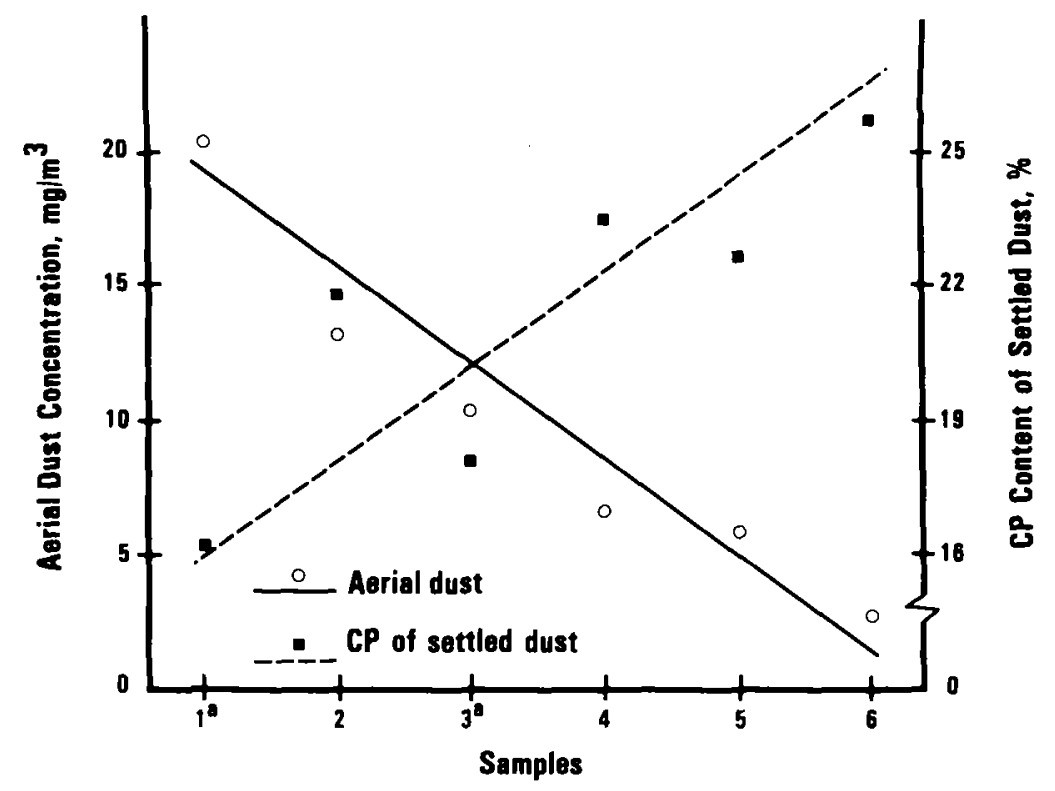

Figure 7. The relationship of aerial dust levels and crude protein (CP) content of settled dust (trials 3 and 4 ). Mean total aerial dust concentrations of both treatments and trials are plotted in descending order and $C P$ contents of settled dust are plotted against those points. ${ }^{2}$ Trial 1 . Correlation coefficient: $-.87(\mathbf{P}<.05)$.

cavity. These entrapped particles are transported by ciliary action to the pharynx and swallowed (Switzer et al., 1981). When these functions cannot be adequately performed by the nasal passages due to the damaged turbinates, antigenic and non-antigenic particles may reach the lower respiratory tract where they may cause or aggravate disease conditions (Jericho, 1968). Switzer et al. (1981) noted that dust accumulation in swine buildings can be a contributing factor in intensifying pneumonia, especially in pigs that have atrophic rhinitis.

TABLE 11. EFFECT OF DIETARY TALLOW ON RESPIRATORY STRUCTURE OF SWINE REARED IN ENVIRONMENTALLY REGULATED BUILDINGS (TRIALS 3 AND 4) a $^{a}$

\begin{tabular}{|c|c|c|c|c|c|c|c|c|c|c|c|}
\hline \multirow[b]{3}{*}{ Scoreb } & \multirow{3}{*}{$\begin{array}{l}\text { Trial: } \\
\text { Diet: }\end{array}$} & \multicolumn{6}{|c|}{ Lung lesions } & \multicolumn{4}{|c|}{ Pigs with abnormal turbinates } \\
\hline & & \multicolumn{2}{|c|}{3 (spring) } & \multicolumn{2}{|c|}{4 (fall) } & \multicolumn{2}{|c|}{ Combined } & \multicolumn{2}{|c|}{3 (spring } & \multicolumn{2}{|c|}{4 (fall) } \\
\hline & & 1 & 2 & 1 & 2 & 1 & 2 & 1 & 2 & 1 & 2 \\
\hline 0 & & 3 & 7 & 6 & 5 & 9 & 12 & 0 & 0 & 1 & 1 \\
\hline $1 \mathrm{de}$ & & 16 & 5 & 1 & 3 & 17 & 8 & 6 & 1 & 0 & 1 \\
\hline $2^{e}$ & & 5 & 9 & 5 & 12 & 10 & 21 & 1 & 0 & 3 & 4 \\
\hline 3 & & 3 & 3 & 10 & 7 & 13 & 10 & 1 & 1 & 2 & 4 \\
\hline 4 & & 2 & 5 & 4 & 1 & 6 & 6 & $i$ & 2 & 1 & 0 \\
\hline 5 & & 2 & 3 & 0 & 0 & 2 & 3 & 1 & 3 & 0 & 0 \\
\hline 6 & & 0 & 0 & 0 & 0 & 0 & 0 & 0 & 0 & 0 & 0 \\
\hline Total & & 31 & 32 & 26 & $\overrightarrow{28}$ & 57 & 60 & 10 & 7 & 7 & 10 \\
\hline
\end{tabular}

${ }^{a}$ Diet 1 : containing $5 \%$ added tallow; diet 2 : containing no added tallow.

$\mathrm{b}_{0}=$ free of gross lesions; 1 = very mild lesions; $2=$ mild lesions; $3=$ moderate lesions; 4 = moderate to severe lesions; 5 = severe lesions; 6 = very severe lesions (Huhn, 1970).

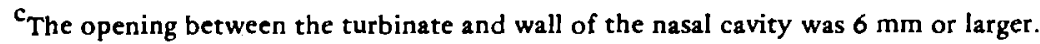

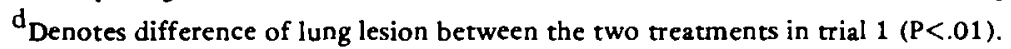

${ }^{e}$ Denotes difference of lung lesion between the two treatments in combined data $(P<.05)$. 
Overall mean total concentrations of aerial dust (figure 6) were lower in ER buildings than MOF buildings. This was probably due to several reasons: (1) aerial dust levels tend to be lower at warmer temperatures (Curtis et al., 1975b), (2) the MOF buildings were closed completely during most of the study period (November, 1982 to February, 1983), whereas the air (consequently dust) was removed mechanically in trials 3 and 4 and (3) an automated feed distribution system was used in the MOF buildings (thus generating more dust during the feeding process).

Mechanical ventilation seems to be a partially effective and practical way of removing the particulate matter from swine buildings (Curtis et al., 1972; Bundy et al., 1974; Bundy and Hazen, 1975). Thus, a mechanical ventilation system, along with addition of fat to swine diets, can contribute to a substantial reduction in aerial dust concentrations. However, Preuschen (1974) and Curtis (1981) cautioned that potential airborne materials are drier with greater ventilation rates, and this may exacerbate dusty situations in swine confinement. Also, the ventilation (and subsequently lower relative humidity) tends to dry the bronchial mucosae, and this may stop ciliary beating and transport (Kilburn, 1967; Jericho, 1968; Honey and McQuitty, 1976), thus interfering with the primary clearance function of the mucus blanket in the respiratory tract. A reduced efficiency of mucociliary apparatus creates favorable conditions for antigenic and nonantigenic substances to penetrate into the lower respiratory systems (Gross, 1967; Jericho, 1968; Cermak and Ross, 1978).

The effect of $5 \%$ dietary fat upon reduction of aerial dust appears to be consistent. In the trials with MOF buildings, the reduction in aerial dust was $49 \%$. In the trials with mechanically ventilated buildings, the reductions were 48 and $51 \%$ (trials 3 and 4 , respectively), very similar to the dust reduction observed with MOF buildings.

\section{Literature Cited}

Addleman, S. 1969. The generalized randomized block design. Amer. Statist. 23(4): 35.

Ames, D. R. and D. E. Ray. 1983. Environmental manipulation to improve animal productivity. J. Anim. Sci. 57(Suppl. 2): 209.

AOAC. 1980. Official Methods of Analysis (13th Ed.). Association of Official Analytical Chemists, Washington, DC.

Barrick, E. R., T. N. Blumer, W. L. Brown, F. H.
Smith, S. B. Tove, H. L. Lucus and H. A. Stewart. 1953. The effect of feeding several kinds of fat on feedlot performance and carcass characteristics of swine. J. Anim. Sci. 12:899 (Abstr.).

Bond, T. E. 1974. The influence of environmental factors on nonruminant production. Proc. Int. Livestock Environ. Symposium, Amer. Soc. Agr. Eng., St. Joseph, MI.

Bundy, D. S. and T. E. Hazen. 1975. Dust levels in swine confinement systems associated with different feeding methods. Trans. Amer. Soc. Agr. Eng. 18:137.

Bundy, D. S., T. E. Hazen and L. H. Soderholm. 1974. Dust control in swine-confinement buildings by a corona discharge. Proc. Int. Livestock Environ. Symposium, Amer. Soc. Agr. Eng., St. Joseph, Ml.

Burnett, W. E. 1969. Odor transport by particulate matter in high density poultry houses. Poul. Sci. 48:182.

Cermak, J. P. and P. A. Ross. 1978. Airborne dust concentration associated with animal housing tasks. Farm Building Progress 51:11.

Clawson, A. J., T. H. Blumer, W.W.G. Smart, Jr. and E. R. Barrick. 1962. Influence of energy: protein ratio on performance and carcass characteristics of swine. J. Anim. Sci. 21:62.

Curtis, S. E. 1972. Air environment and animal performance. J. Anim. Sci. 35:628.

Curtis, S. E. 1981. Environmental Management in Animal Agriculture. Animal Environmental Services, Mahomet, IL.

Curtis, S. E., C. R. Anderson, J. Simon, A. H. Jensen, D. L. Day and K. W. Kelley. 1975a. Effects of aerial ammonia, hydrogen sulfide and swinehouse dust on rate of gain and respiratory tract in swine. J. Anim. Sci. 41:735.

Curtis, S. E., J. G. Drummond, D. J. Grunloh, P. B. Lynch and A. H. Jensen. 1975b. Relative and qualitative aspects of aerial bacteria and dust in swine houses. J. Anim. Sci. 41:1512.

Curtis, S. E., D. J. Grunloh, A. H. Jensen, J. Simon, B. G. Harmon and D. H. Baker. 1972. Studies on the pig's air environment: A progress report. Illinois Pork Industry Day, Anim. Sci. Dept. AS-661f. Univ. of Illinois, Urbana-Champaign.

Day, B. N., G. C. Anderson, V. K. Johnson and W. L. Lewis. 1953. The effect of a high fat ration on swine gain and carcass quality. J. Anim. Sci. 12:944 (Abstr.).

Day, D. L., E. L. Hansen and A. Anderson. 1965. Gases and odors in confinement swine buildings. Trans. Amer. Soc. Agr. Eng. 8:118.

Donham, K. J. and K. F. Gustafson. 1982. Human occupational hazards from swine confinement. Ann. Amer. Conf. Gov. Hyg. 2:137.

Feddes, J.J.R. and J. B. McQuitty. 1983. Gasses and dust in confinement barns. Guelph Pork Symposium Proceedings, Univ. of Guelph and Ontario Ministry of Agr. and Food. pp 45-53.

Fritschen, R.D. and A. Hogg. 1983. Preventing tail biting in swine. NebGuide. Pub. No. G75-246 (Revised Ed.). Univ. of Nebraska, Lincoln.

Fritschen, R. D. and E. R. Peo, Jr. 1979. Swine nutrition and housing. Nebraska Swine Report. Pp 19-20. 
Green, J. 1983. Incorrect economic assessment of feed performance. Feedstuffs 55(51): 19.

Gross, P. 1967. The mechanism of some structural alterations of the lung caused by environmental health. Arch. Environ. Health 14:883.

Hammond, E. G., C. Fedler and G. Junk. 1979. Identification of dust-borne odors in swine confinement facilities. Trans. Amer. Soc. Agr. Eng. 22:1186.

Harry, E. G. 1964. The survival of E. coli in the dust of poultry houses. Vet. Rec. 76(17): 466 .

Heitman, H., Jr. 1956. Use of stabilized tallow in swine rations. J. Anim. Sci. 15:1046.

Heitman, H., Jr., C. F. Kelly and T. E. Bond. 1958. Ambient air temperature and weight gain in swine. J. Anim. Sci. 17:62.

Honey, L. F. and J. B. McQuitty. 1979. Some physical factors affecting dust concentrations in a pig facility. Can. Agr. Eng. 21(1):9.

Huhn, R. G. 1970. Swine enzootic pneumonia: Incidence and effect on rate of body weight gain. Amer. J. Vet. Res. 31:1097.

Jacobson, L. D. 1974. Bacterial and particulate concentration in a turkey house environment. M.S. Thesis. Univ. of Minnesota, St. Paul.

Jericho, K.W.F. 1968. Pathogenesis of pneumonia in pigs. Vet. Rec. 82:507.

Keaschall, K. E., B. D. Moser, E. R. Peo, Jr., A. J. Lewis and T. D. Crenshaw. 1983. "Dried fat" for growing-finishing swine. J. Anim. Sci. 56:286.

Kilburn, K. H. 1967, Cilia and mucus transport as determinants of the response of lung to air pollutants. Arch. Environ. Health 14:77.

Martin, S. W. and R. A. Willoughby. 1972. Organic dust, sulfur dioxide and the respiratory tract of swine. Arch. Environ. Health $25: 158$.

Morrison, S. R., T. E. Bond and P. Finn-Kelcey. 1966. The influence of humidity on growth rate and feed utilization of swine. Int. J. Biometeor. $10: 163$

Morrison, S. R., H. Heitman, Jr. and T. E. Bond. 1969. Effect of humidity on swine at temperatures above optimum. Int. J. Biometeor. 13:135.

Moser, B. D. 1977. Feeding animal fat to growing and finishing pigs. Feedstuffs 49(15): 20 .

Moser, B. D. and A. J. Lewis. 1980. Adding fat to sow diet - An update. Feedstuffs 52(9): 36 .
Moser, B. D. and A. J. Lewis. 1981. Fat addition to sow diets - A review. Pig News Inform. 2(3): 265 .

Moser, B. D., E. R. Peo, Jr., T. Stahly and M. K. Nielsen. 1975. Fat additions to normal and opaque-2 corn diets for G-F swine. J. Anim. Sci. $41: 322$ (Abstr.).

Muir, D.C.F. 1983. Noise, dust, gases and human health. Guelph Pork Symposium Proceedings, Univ. of Guelph and Ontario Ministry of Agr. and Food. pp 54-58.

Notestine, J. C. and D. L. Pfost. 1965. Dust problems in livestock environment. Trans. Amer. Soc. Agr. Eng. 8:340.

Owen, J. E. 1982. Dust - The problem and possibilities. Farm Building Progress 67:3.

Peo, E. R., Jr. and L. I. Chiba. 1984. Use of inedible animal fats to reduce feed dust in swine finishing facilities explored. Feedstuffs 56(10): 38 .

Preuschen, G. 1974. Air pollution and human work capacity. Proc. Int. Livestock Environ. Symposium, Amer. Soc. Agr. Eng., St. Joseph, MI.

SAS. 1979. SAS User's Guide. Statistical Analysis System Institute, Inc., Cary, NC.

Scott, N. R., J. A. DeShazer and W. L. Roller. 1983. Effects of thermal and gaseous environment on livestock. In: M. A. Hellickson and J. N. Walker (Ed.) Ventilation of Agricultural Structures. pp 121-165. Amer. Soc. Agr. Eng., St. Joseph, MI.

Sewell, R. F., R. L. Tarpley and R. P. Abernathy. 1958. Effect of adding a cholagogue to rations for growing swine at three levels of dietary fat. $J$. Anim. Sci. 17:47.

Shelton, D. P. and D. D. Schulte. 1982. Vented and unvented furnaces for swine housing. Proc. Int. Livestock Environ. Symposium, Amer. Soc. Agr. Eng., St. Joseph, MI.

Steel, R.G.D. and J. H. Torrie. 1980. Principles and Procedures of Statistics (2nd Ed.). McGraw-Hill Book Co., New York.

Switzer, W. P., R. L. Engen, N. G. Ghoshal and J. P. Kunesh. 1981. Respiratory system. In: A. D. Leman, R. D. Glock, W. L. Mengeling, R.H.C. Penny, E. Scholl and B. Straw (Ed.) Diseases of Swine (5th Ed.). Iowa State Univ. Press, Ames.

Wilder, O.H.M. 1960. The story of fats in feeds. The Utilization of Animal Fats. American Meat Institute Foundation, Chicago. pp 40:46. 